\title{
Microbially-accelerated consolidation of oil sands tailings. Pathway II: solid phase biogeochemistry
}

\section{Tariq Siddique ${ }^{1 *}$, Petr Kuznetsov ${ }^{1}$, Alsu Kuznetsova ${ }^{1}$, Carmen Li $^{2}$, Rozlyn Young ${ }^{2}$, Joselito M. Arocena ${ }^{3}$ and Julia M. Foght ${ }^{2}$}

1 Department of Renewable Resources, University of Alberta, Edmonton, AB, Canada

${ }^{2}$ Department of Biological Sciences, University of Alberta, Edmonton, AB, Canada

${ }^{3}$ Environmental Science and Engineering, University of Northern British Columbia, Prince George, BC, Canada

Edited by:

Jason Raymond, Arizona State

University, USA

Reviewed by:

Amy Michele Grunden, North

Carolina State University, USA

Mark Alexander Lever, Aarhus

University, Denmark

\section{*Correspondence:}

Tariq Siddique, Department of

Renewable Resources, University of

Alberta, 442-Earth Sciences

Building, Edmonton, AB T6G 2E3,

Canada

e-mail: tariq.siddique@ualberta.ca
Consolidation of clay particles in aqueous tailings suspensions is a major obstacle to effective management of oil sands tailings ponds in northern Alberta, Canada. We have observed that microorganisms indigenous to the tailings ponds accelerate consolidation of mature fine tailings (MFT) during active metabolism by using two biogeochemical pathways. In Pathway I, microbes alter porewater chemistry to indirectly increase consolidation of MFT. Here, we describe Pathway II comprising significant, direct and complementary biogeochemical reactions with MFT mineral surfaces. An anaerobic microbial community comprising Bacteria (predominantly Clostridiales, Synergistaceae, and Desulfobulbaceae) and Archaea (Methanolinea/Methanoregula and Methanosaeta) transformed $\mathrm{Fe}^{\text {III }}$ minerals in MFT to amorphous Fell minerals during methanogenic metabolism of an added organic substrate. Synchrotron analyses suggested that ferrihydrite $\left(5 \mathrm{Fe}_{2} \mathrm{O}_{3} \cdot 9 \mathrm{H}_{2} \mathrm{O}\right)$ and goethite $(\alpha-\mathrm{FeOOH})$ were the dominant Fe ${ }^{\text {Ill }}$ minerals in MFT. The formation of amorphous iron sulfide (FeS) and possibly green rust entrapped and masked electronegative clay surfaces in amended MFT. Both Pathways I and II reduced the surface charge potential (repulsive forces) of the clay particles in MFT, which aided aggregation of clays and formation of networks of pores, as visualized using cryo-scanning electron microscopy (SEM). These reactions facilitated the egress of porewater from MFT and increased consolidation of tailings solids. These results have large-scale implications for management and reclamation of oil sands tailings ponds, a burgeoning environmental issue for the public and government regulators.

Keywords: methanogenesis, Fe $\mathrm{III}^{\mathrm{II}}$ reduction, formation of Fe"l minerals, aggregation of clay particles, consolidation, oil sands tailings

\section{INTRODUCTION}

Aqueous slurries with appreciable clay content (e.g., mine tailings and unconsolidated sediments) are generated worldwide by industrial activities, particularly during ore processing. For example, $\sim 1$ million $\mathrm{m}^{3}$ of fluid fine tailings day ${ }^{-1}$ are generated during bitumen extraction from surface-mined oil sands ores in northern Alberta, Canada. These wastes are deposited into tailings ponds for containment under a policy of no release to the environment. The implementation of government directives specifying oil sands tailings performance criteria and reduction of tailings volumes has concentrated industry efforts to develop cost-effective technologies for treating these fluid tailings. Strategies include dewatering (recovery of pore water from tailings suspensions for re-use in bitumen extraction) and consolidation of solids (to decrease tailings inventory) after placement in tailings ponds. This poses a major challenge to oil sands companies because gravitational settling of fine colloidal clay suspensions takes years or decades to achieve even $30-35 \%$ solids content as mature fine tailings (MFT). Chemical additives (e.g., gypsum) used to consolidate the "fines" can deteriorate the quality of recovered water for re-cycling and can cause unanticipated hazardous side-effects in the ponds (e.g., biogenic $\mathrm{H}_{2} \mathrm{~S}$ ); physical treatments such as centrifugation are cost- and energy-intensive. Addition of flocculants and coagulants such as polyacrylamide to alter tailings properties (e.g., www.suncor. com/tailings) has unknown long-term stability and environmental impact (e.g., polymer degradation to toxic acrylamide). In contrast, microbially-mediated dewatering and consolidation of fine tailings ("biodensification") relies on microbes naturally present in tailings ponds (Fedorak et al., 2003), likely supported in situ by biodegradation of diluent hydrocarbons (Siddique et al., $2006,2007,2011,2012)$. In the laboratory, we have accelerated biodensification of MFT by adding fermentable organic carbon sources to stimulate the indigenous microbes: faster dewatering and consolidation were observed with MFT from all five oil sands tailings ponds tested from three different operators, indicating that this is a general response (Bressler et al., 2010).

To reveal the fundamental mechanisms of biodensification, a 50-L column experiment was conducted to investigate the effects of microbial metabolism on physical, chemical, and mineralogical properties of MFT. We discovered two microbially-mediated geochemical pathways (Figure 1) that increased consolidation 

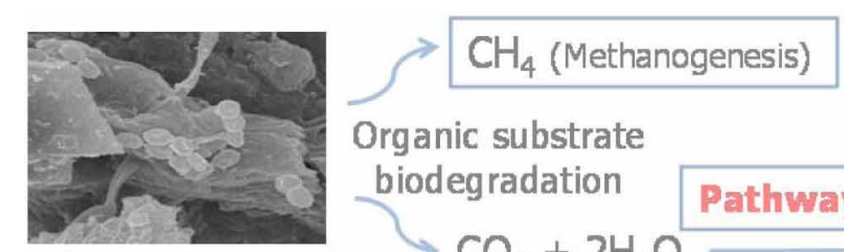

Organic substrate

biodeg radation

Microbes in

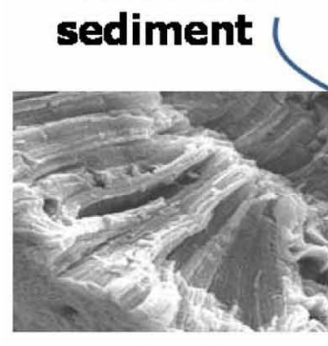

$\longrightarrow \mathrm{CO}_{2}+2 \mathrm{H}_{2} \mathrm{O} \longrightarrow \mathrm{HCO}_{3}{ }^{-}+\mathrm{H}_{3} \mathrm{O}^{+}$

Pathway I
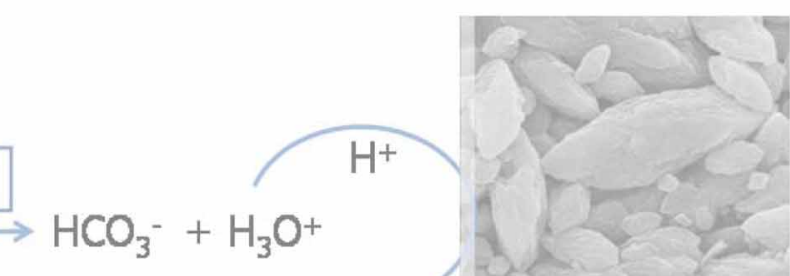

$(\mathrm{Ca}, \mathrm{Mg}) \mathrm{CO}_{3}$

FeOOH

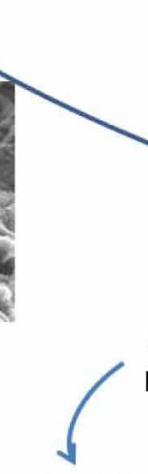

Pathway II
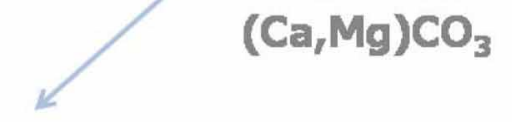
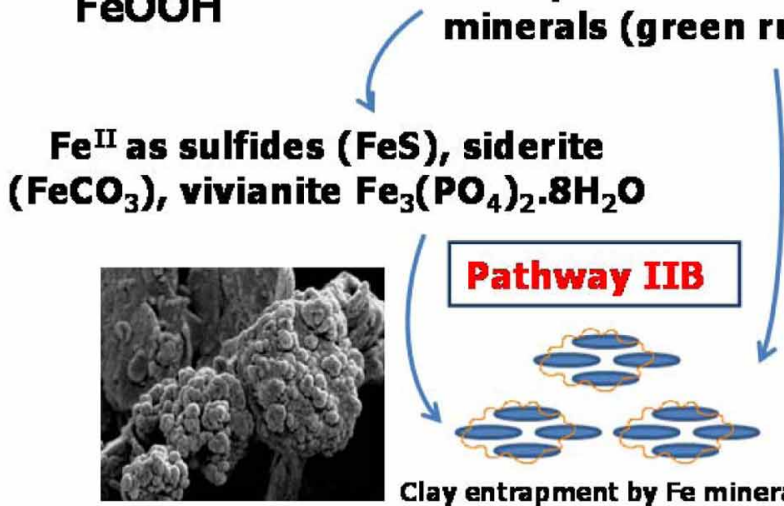

Clay entrapment by Fe minerals
FIGURE 1 | Proposed model for microbially-mediated geochemical pathways of clay consolidation, modified from Figure 7 in companion paper (Siddique et al., 2014). In Pathway I, microbial metabolism decreases $\mathrm{pH}$ and dissolves carbonate minerals in MFT, increasing bicarbonate $\left(\mathrm{HCO}_{3}^{-}\right)$, calcium $\left(\mathrm{Ca}^{2+}\right)$, and magnesium $\left(\mathrm{Mg}^{2+}\right)$ ions in porewater. These ions increase ionic strength (/) of porewater, thus reducing the diffuse double layer (DDL) of clay particles and facilitating their consolidation. In Pathway II under anaerobic conditions, $\mathrm{Fe}^{\mathrm{III}}$ minerals (goethite and ferrihydrite; $\mathrm{FeOOH}$ ) in tailings are reduced to $\mathrm{Fe}^{l l}$ as dissolved $\mathrm{Fe}^{2+}$ that may contribute to the cation exchange process (Pathway IIA) and/or to formation of mixed-valence Fe $\mathrm{F}^{\text {II }} \mathrm{Fe} \mathrm{e}^{\text {III }}$ "green rust." Dissolved $\mathrm{Fe}^{2+}$ and/or green rust react with $\mathrm{H}_{2} \mathrm{~S}$ (aqueous), $\mathrm{HS}^{-}, \mathrm{PO}_{4}^{3-}$, or $\mathrm{HCO}_{3}^{-}$to form $\mathrm{FeS}, \mathrm{FeCO}_{3}$, and $\mathrm{Fe}_{3}\left(\mathrm{PO}_{4}\right)_{2} \cdot 8 \mathrm{H}_{2} \mathrm{O}$ minerals. Transformed minerals entrap clay particles and/or mask the reactive surfaces of clays, increasing clay particle consolidation (Pathway IIB). Competing reactions are shown by solid arrows while dashed arrows indicate pathways not considered significant in our study. CEC, cation exchange capacity. and dewatering of MFT. Pathway I, described in a companion paper (Siddique et al., 2014), involves alteration of pore water chemistry via biogenic $\mathrm{CO}_{2}$ production, indirectly increasing MFT consolidation. However, those experimental observations also revealed that Pathway I alone was not sufficient to achieve significant tailings consolidation: when exogenous $\mathrm{CO}_{2}$ was abiotically purged through the MFT, pore water recovery and MFT consolidation were only slightly increased (Siddique et al., 2014). In contrast, we observed that when biogenic methane and $\mathrm{CO}_{2}$ were produced slowly and constantly throughout the tailings during anaerobic metabolism, pore water and clay surface chemistry were altered and physical channels for water transport were created as the organic substrates were depleted. Therefore, in this study we investigated in detail the clay-microbe interactions in MFT samples retrieved after 213 days of incubation, analyzing solid phase chemistry to complement pore water chemistry (Siddique et al., 2014). Based on those results, we propose Pathway II (Figure 1) that is more direct and is complementary to Pathway I to fully describe tailings consolidation and dewatering. This comprehensive study reveals potential microbial repercussions for oil sands tailings ponds management and reclamation strategies, as well as general biogeochemical processes that may influence behavior of unconsolidated clayand organic-rich sediments such as contaminated riverbeds and harbors.

\section{MATERIALS AND METHODS}

\section{PREPARATION AND SAMPLING OF 50-L COLUMNS}

An experiment was conducted in 50-L columns using MFT collected from Mildred Lake Settling Basin at Syncrude Canada Ltd. in Fort McMurray, Alberta, Canada (Figure A1). Detailed information about setting up this experiment has been described by 
Siddique et al. (2014). Briefly, two 50-L acrylic columns were each filled with $45 \mathrm{~L}$ MFT under a curtain of $\mathrm{N}_{2}$ gas and sealed with an $\mathrm{N}_{2}$ headspace to maintain anaerobic conditions. One column contained MFT amended with hydrolyzed canola meal as carbon source (final concentration $400 \mathrm{mg} \mathrm{C} \mathrm{L}^{-1}$ tailings) to enhance indigenous microbial activity. The canola is not considered a source of viable microbes nor amplifiable DNA because it was hydrolyzed at high $\mathrm{pH}$ and $60^{\circ} \mathrm{C}$ for $24 \mathrm{~h}$. Parallel experiments have not revealed any contributions of microbes from canola amendment to the tailings community (manuscript in preparation). This amendment had been determined previously to promote MFT consolidation at this concentration (Bressler et al., 2010); its preparation is described in Table 2 of a companion paper (Siddique et al., 2014). The other column contained unamended MFT as a baseline control in which only endogenous carbon was available to support microbial activity. The columns were incubated undisturbed in dim light at $\sim 20^{\circ} \mathrm{C}$ for 213 days. Experimental details and analytical approach for determining biogenic gas production and composition, in situ $\mathrm{pH}$, porewater recovery and consolidation of tailings, soluble cations, and anions, exchangeable cations, and carbonates minerals have been described in a companion paper (Siddique et al., 2014). The same samples were subjected to solid phase biogeochemical analyses including fractionation of iron ( $\mathrm{Fe}$ ) and sulfides, mineralogy of solid phase by Scanning Electron Microscopy (SEM) and synchrotron-based X-ray Absorption Near-Edge Structure (XANES) and characterization of microbial communities by $16 \mathrm{~S}$ rRNA gene pyrosequencing as described below in this section.

\section{CHEMICAL METHODS}

\section{Total metals in MFT solid phase}

An acid digestion method (US EPA, 2007) originally designed for sediments, sludge, and soil was used for MFT samples. One gram of solid matrix was separated from MFT by centrifugation under anaerobic conditions, placed in a Teflon digestion vessel and $5 \mathrm{~mL}$ $\mathrm{H}_{2} \mathrm{O}$ (nanopure) and $10 \mathrm{~mL}$ of $76 \% \mathrm{HNO}_{3}$ (trace metal grade) were added. Digestion was performed in a microwave (ETHOS SEL High Performance Extraction System) for $20 \mathrm{~min}$ at $180^{\circ} \mathrm{C}$. After digestion, filtration $(0.45 \mu \mathrm{m}$ pore size $)$ and dilution with $1 \% \mathrm{HNO}_{3}$, the samples were analyzed using inductively coupled plasma mass spectrometry (ICP-MS) (PerkinElmer SCIEX ELAN 9000) and results were calculated on a dry weight basis. This acid digestion dissolves almost all metals that could become "environmentally available" (Kimbrough and Wakakuwa, 1989). Elements bound in silicate structures are not normally dissolved by this procedure; however, $\mathrm{HNO}_{3}$ treatment with heating can dissolve some clay minerals, e.g., illite and chlorite (Komadel and Madejová, 2006).

For sulfide and Fe fractionation, MFT samples were collected in airtight bottles (Oak Ridge $50 \mathrm{~mL}$ centrifuge tubes and Nalgene $250 \mathrm{~mL}$ centrifuge bottles with sealing caps) under $\mathrm{N}_{2}$ headspace using a continuous stream of $\mathrm{N}_{2}$. All further sample manipulations were carried out in "Hands-In-Bag" (Spilfyter, Green Bay WI, USA) under an $\mathrm{N}_{2}$ atmosphere. For Fe fractionation, MFT samples were centrifuged ( $3075 \mathrm{~g}$ for $1 \mathrm{~h}$ ) in a Sorvall RC 5B centrifuge to collect the solids phase whereas whole MFT was used for sulfide fractionation to avoid any $\mathrm{H}_{2} \mathrm{~S}$ gas loss during sample manipulation.

\section{Sulfide minerals}

Different forms of sulfides such as free hydrogen sulfide $\left(\mathrm{H}_{2} \mathrm{~S}\right.$ gas), acid-volatile sulfides (AVS; amorphous and poorly crystalline monosulfides), and chromium (Cr)-reducible sulfides (Cr-R; all sulfides) were determined in the MFT samples. For $\mathrm{H}_{2} \mathrm{~S}$ determination, $\sim 3 \mathrm{~g}$ of MFT was placed in a pre-weighed vacuum flask under $\mathrm{N}_{2}$ atmosphere. The flask was connected by tubing to an Erlenmeyer flask with $30 \mathrm{~mL}$ aqueous zinc acetate solution used as a "trap" for $\mathrm{H}_{2} \mathrm{~S}$. The sample was continuously flushed with $\mathrm{N}_{2}$ and stirred for $1 \mathrm{~h}$. Free $\mathrm{H}_{2} \mathrm{~S}$ was trapped and titrated iodometrically with starch solution as an indicator (Allen et al., 1993; Pansu and Gautheyrou, 2006). Results were reported as sulfur content on a dry weight basis.

Subsequently, for AVS determination, using a syringe $20 \mathrm{~mL}$ $6 \mathrm{~N} \mathrm{HCl}$ (Morse and Cornwell, 1987) was injected into the same rubber-stoppered flask and the sample was continuously stirred for $2 \mathrm{~h}$. The digested AVS were trapped in a separate flask containing $30 \mathrm{~mL}$ aqueous zinc acetate solution that was analyzed for $S$ by titrating with iodine solution in presence of starch indicator to blue end-point (Ahern et al., 1998; Pansu and Gautheyrou, 2006). Allen et al. (1993) reported that this method was capable of recovering more than $90 \%$ of the AVS. AVS usually refers to greigite $\left(\mathrm{Fe}_{3} \mathrm{~S}_{4}\right)$, mackinawite $\left(\mathrm{FeS}_{0.94}\right)$, and amorphous sulfide (FeS) minerals (Ahern et al., 1998; Pansu and Gautheyrou, 2006). In our experimental $\mathrm{pH}$-Eh conditions, mackinawite is assumed to predominate (Rickard and Luther, 2007). Under our experimental conditions the term "amorphous sulfides" includes mackinawite and amorphous sulfide (Rickard and Luther, 2007).

For Cr-R sulfides, about $5 \mathrm{~g}$ of MFT was placed in a tared round-bottom three-neck flask under $\mathrm{N}_{2}$ atmosphere. The flask was connected through a condenser to an Erlenmeyer flask containing a zinc acetate solution. The sample flask was connected to a $\mathrm{N}_{2}$ gas cylinder for continuous flow of $\mathrm{N}_{2}$ gas through the apparatus. About $2 \mathrm{~g}$ of $\mathrm{Cr}$ powder and $60 \mathrm{~mL} 5.65 \mathrm{M} \mathrm{HCl}$ were added to the sample flask. The sample was digested on a hot plate for $1 \mathrm{~h}$ (Ahern et al., 1998) then the zinc acetate solution was titrated iodometrically using starch solution as an indicator (Allen et al., 1993; Pansu and Gautheyrou, 2006). Results were calculated as sulfur content on a dry weight basis.

\section{Phosphate minerals}

For determining Al- and Fe-bound $\mathrm{P}$ (mainly $\mathrm{Al}$ and Fe phosphates, phosphate adsorbed on Fe oxides and other sorbents, and $\mathrm{P}$ in organic components) (Olsen and Sommers, 1982; Kuo, 1996), $1 \mathrm{~g}$ MFT was treated with $50 \mathrm{~mL} 0.1 \mathrm{M} \mathrm{NaOH} / 1 \mathrm{M} \mathrm{NaCl}$ solution, shaken for $16 \mathrm{~h}$ and centrifuged to separate the supernatant $(3075 \mathrm{~g}$ for $1 \mathrm{~h}$ ). The phosphorus in the supernatant was determined using the ascorbic acid method and a UV/VIS spectrophotometer (Optizen POP) at $\lambda 880 \mathrm{~nm}$ (Kuo, 1996).

\section{Iron (Fe) minerals}

Both selective dissolution and direct determination of Fe were used for Fe fractionation in MFT. Total Fe was determined using ICP-MS analysis after acid digestion, as described above for total 
metals. The ferrozine-extractable $\mathrm{Fe}^{\mathrm{II}}$ in the solid phase was determined by using a ferrozine method used for the estimation of available Fe ${ }^{\mathrm{II}}$ (Sorensen, 1982; Lovley and Phillips, 1986). About $0.3 \mathrm{~g}$ MFT solid phase was added to $5 \mathrm{~mL}$ of $0.1 \%$ ferrozine prepared in a $0.05 \mathrm{M}$ HEPES buffer solution in air-tight tubes under $\mathrm{N}_{2}$ headspace. The MFT with ferrozine solution was shaken for $15 \mathrm{~min}$ and then centrifuged. The supernatant was analyzed for $\mathrm{Fe}^{\mathrm{II}}$ using an UV/VIS spectrophotometer (Optizen POP) at $562 \mathrm{~nm}$. To avoid any oxidation of $\mathrm{Fe}^{\mathrm{II}}$, all MFT manipulations (before addition of ferrozine solution) were performed under $\mathrm{N}_{2}$ atmosphere in "Hands-In-Bag" (Spilfyter). To avoid dissolution of accessory minerals by $\mathrm{HCl}$ (Wallmann et al., 1993; van der Zee et al., 2002), $\mathrm{HCl}$ as an extractant was not used in the analysis.

Dithionite-citrate-bicarbonate (DCB)-extractable $\mathrm{Fe}$ was determined by treating the MFT solid phase with DCB solution ( $\mathrm{pH}$ 7). This method was used to extract the total $\mathrm{Fe}$ oxides and hydroxides from soils by reductive dissolution (Mehra and Jackson, 1960; Munch and Ottow, 1980; Pansu and Gautheyrou, 2006). Two grams of MFT solid phase were placed in a $100-\mathrm{mL}$ tube and $45 \mathrm{~mL}$ of citrate-bicarbonate buffer $(\mathrm{pH}$ 7.3) were added. The sample tube was incubated in a water bath at $75^{\circ} \mathrm{C}$ and continuously stirred. One gram of sodium dithionite $\left(\mathrm{Na}_{2} \mathrm{~S}_{2} \mathrm{O}_{4}\right)$ powder was added to the sample when it reached $75^{\circ} \mathrm{C}$ and a second dose $(1 \mathrm{~g})$ was added after $5 \mathrm{~min}$. After $15 \mathrm{~min}$, the sample was centrifuged and the supernatant was transferred to a $250-\mathrm{mL}$ volumetric flask. The sample was treated again with citrate-bicarbonate buffer for a second extraction with two additional doses of $\mathrm{Na}_{2} \mathrm{~S}_{2} \mathrm{O}_{4}$. After centrifugation, both supernatants were pooled and analyzed for Fe by atomic absorption spectroscopy (AAS). DCB extraction dissolves most $\mathrm{Fe}$ oxides and oxyhydroxides (both $\mathrm{Fe}^{\mathrm{II}}$ and $\mathrm{Fe}^{\mathrm{III}}$ ) including ferrihydrite $\left(5 \mathrm{Fe}_{2} \mathrm{O}_{3} \cdot 9 \mathrm{H}_{2} \mathrm{O}\right)$, lepidocrocite $(\gamma-\mathrm{FeOOH})$, goethite $(\alpha-\mathrm{FeOOH})$, akaganeite $(\beta-\mathrm{FeOOH})$, green rust $\left(\mathrm{Fe}_{3}(\mathrm{OH})_{8}\right)$, and hematite $\left(\alpha \mathrm{Fe}_{2} \mathrm{O}_{3}\right)$. This extraction also partly dissolves monosulfides (FeS) (Heron et al., 1994) but does not affect siderite $\left(\mathrm{FeCO}_{3}\right)$ and pyrite $\left(\mathrm{FeS}_{2}\right)$ (Lord, 1982; Fine and Singer, 1989; Vodyanitskii et al., 2007). Therefore, DCB extraction is shown to extract both crystalline and amorphous minerals, mostly Fe $\mathrm{Fe}^{\mathrm{II}, \mathrm{III}}$ (oxyhydr) oxides.

The ammonium oxalate (AO)-extractable Fe was determined using AO buffer in the dark (AOD), which is commonly used for the determination of amorphous and poorly crystalline Fe oxides and hydroxides in soils (McKeague and Day, 1966; Munch and Ottow, 1980; Pansu and Gautheyrou, 2006) or Fe $\mathrm{F}^{\mathrm{III}}$ in sediments (Phillips and Lovley, 1987). One gram of MFT solid phase was placed in a centrifuge tube with $50 \mathrm{~mL}$ of AOD $(\mathrm{pH} \sim 3)$. The sample was shaken for $4 \mathrm{~h}$ in darkness and centrifuged $(3075 \mathrm{~g}$ for $1 \mathrm{~h}$ ), and the supernatant was analyzed for Fe by AAS. Studies have shown that $\mathrm{AO}$ extracts crystalline akaganeite and magnetite $\left(\mathrm{FeO} \cdot \mathrm{Fe}_{2} \mathrm{O}_{3}\right.$ ) (Borggaard, 1988; Heron et al., 1994; Poulton and Canfield, 2005) and some crystalline goethite and hematite, because a significant amount of $\mathrm{Fe}^{\mathrm{II}}$ extracted in the $\mathrm{AO}$ solution catalyzes the dissolution of crystalline oxides (Hering and Stumm, 1990; Phillips et al., 1993). Therefore, AOD extractions may overestimate amorphous $\mathrm{Fe}^{\mathrm{III}}$ oxides.

$\mathrm{Fe}^{\mathrm{II}}$ associated with amorphous sulfides (Fe of AVS) was calculated using the molar ratio of Fe to $S$ equivalents (1.7:1) using published approaches (Heron et al., 1994; Kostka and Luther, 1994).

$\mathrm{Fe}^{\mathrm{II}}$ associated with pyrite was calculated by establishing the stoichiometric ratio between pyritic sulfide and its equivalent $\mathrm{Fe}$ using molar ratios (Fe: $\left.\mathrm{S}_{2}=1: 1.1\right)$. Pyritic sulfide was calculated by subtracting AVS-sulfides from $\mathrm{Cr}$-R sulfides.

$\mathrm{Fe}^{\mathrm{II}}$ associated with carbonates was calculated after deducting the mass of carbonates associated with $\mathrm{Ca}$ and $\mathrm{Mg}$ (as $\mathrm{CaCO}_{3}$ and $\mathrm{MgCO}_{3}$ ) from the total carbonates. The remaining carbonates were assumed to be associated with $\mathrm{Fe}$, and a molar ratio of $\mathrm{Fe}: \mathrm{CO}_{3}$ (1:1.07) was used to calculate $\mathrm{Fe}$ associated with carbonates.

$\mathrm{Fe}^{\mathrm{II}}$ associated with phosphates was calculated using the amount of Fe-bound phosphates determined in the preceding section. A molar ratio of $\mathrm{Fe}: \mathrm{P}(2.7: 1)$ was used for the estimation of vivianite $\left(\mathrm{Fe}_{3}\left(\mathrm{PO}_{4}\right)_{2} .8 \mathrm{H}_{2} \mathrm{O}\right)$.

\section{CALCULATING DIFFERENT FRACTIONS OF Fe IN THE MFT $\mathrm{Fe}$ (total)}

Total Fe was determined employing acid $\left(\mathrm{HNO}_{3}\right)$ digestion (US EPA, 2007) using ICP-MS. This method does not dissolve all solid matrices but dissolves almost all compounds that could easily release Fe into the environment, defined as environmentally available Fe. Therefore, the total pool of environmentally available Fe in the MFT samples would be:

$$
\mathrm{Fe}(\text { total })=\mathrm{Fe}_{\text {Acc.M }}+\mathrm{Fe}_{\text {Phyll }}
$$

where $\mathrm{Fe}_{\mathrm{Acc} . \mathrm{M}}$ is the $\mathrm{Fe}$ of accessory minerals (hematite, magnetite, ferrihydrite, goethite, lepidocrocite, siderite, pyrite, amorphous sulfides, green rust etc., i.e., both $\mathrm{Fe}^{\mathrm{III}}$ and $\mathrm{Fe}^{\mathrm{II}}$ ) while $\mathrm{Fe}_{\text {Phyll }}$ is the Fe of phyllosilicates. Elements bound in silicate structures are not normally dissolved by this acid digestion method, however $\mathrm{HNO}_{3}$ treatment with heating can dissolve some clay minerals, e.g., illite and chlorite. Komadel and Madejová (2006) showed that acid solution $(\mathrm{pH}<3)$ even without heating (i.e., at $\sim 20^{\circ} \mathrm{C}$ ) dissolves a portion of phyllosilicates such as smectite and kaolinite.

\section{$\mathrm{Fe}^{\prime \prime \prime}$}

The following equation was used to calculate $\mathrm{Fe}^{\mathrm{III}}$ in the MFT:

$$
\mathrm{Fe}^{\mathrm{III}}=\mathrm{Fe}_{\mathrm{DCB}}-\mathrm{Fe}_{\text {ferrozine }}^{\mathrm{II}}
$$

Dithionite-citrate-bicarbonate (DCB) extraction (described above) dissolves both crystalline and amorphous minerals such as oxides, oxyhydroxides, and hydroxides (Pansu and Gautheyrou, 2006) but does not dissolve $\mathrm{Fe}^{\mathrm{II}}$ minerals such as pyrite and siderite. Lord (1982) showed that in pyrite-rich sediment DCB extracted only Fe oxides (at $\sim 75^{\circ} \mathrm{C}$ ), and pyrite was removed only after extraction with $10 \mathrm{M}$ hydrofluoric acid and quartz-distilled nitric acid. Fine and Singer (1989) showed that DCB extraction removed mostly Fe oxide and oxyhydroxide in soil, and fine-grained fractions were removed better than coarse fractions. Vodyanitskii et al. (2007) reported that in soil containing pyrite and siderite, $\mathrm{AO}$-extractable $\mathrm{Fe}\left(\mathrm{Fe}_{\mathrm{AOD}}\right)$ was greater than DCB-extractable $\mathrm{Fe}\left(\mathrm{Fe}_{\mathrm{DCB}}\right)$ which showed that 
AOD dissolved pyrite and siderite while DCB did not dissolve those minerals.

\section{Amorphous Fe III $^{\text {In }}$}

The mass of amorphous Fe $\mathrm{FII}^{\mathrm{III}}$ was calculated using the following equation:

$$
\text { Amorphous } \mathrm{Fe}^{\mathrm{III}}=\mathrm{Fe}_{\mathrm{AOD}}-\mathrm{Fe}_{\text {siderite }}^{\mathrm{II}}-\mathrm{Fe}_{\mathrm{AVS}}^{\mathrm{II}}-\mathrm{Fe}_{\text {ferrozine }}^{\mathrm{II}}
$$

$\mathrm{Fe}_{\mathrm{AOD}}$ usually refers to non-crystalline (amorphous) Fe compounds (Walker, 1983); $\mathrm{Fe}_{\text {siderite }}$ is $\mathrm{Fe}$ associated with carbonates; $\mathrm{Fe}_{\mathrm{AVS}}$ is associated with gregite $\left(\mathrm{Fe}_{3} \mathrm{~S}_{4}\right)$, mackinawite $\left(\mathrm{FeS}_{0.94}\right)$, and amorphous sulfide (FeS) (Pansu and Gautheyrou, 2006). Under our experimental $\mathrm{pH}$ and $\mathrm{E}_{\mathrm{h}}$ conditions $(\mathrm{Eh}<-100 \mathrm{mV}$ and $\mathrm{pH}>5.5$ ), mackinawite is assumed to predominate (Rickard and Luther, 2007), therefore, we use the term "amorphous sulfide" for both mackinawite and amorphous sulfide minerals (Rickard and Luther, 2007). Fe ferrozine was analyzed using the ferrozine assay (Stookey, 1970) initially developed for $\mathrm{Fe}^{\mathrm{II}}$ analyses in sediment. Sorensen (1982) and Lovley and Phillips (1986) modified the ferrozine method using $\mathrm{HCl}$ to mobilize $\mathrm{Fe}$ and hydroxylamine for transforming $\mathrm{Fe}^{\mathrm{III}}$ to $\mathrm{Fe}^{\mathrm{II}}$.

AO-buffer at $\mathrm{pH} \sim 3.0$ also dissolves siderite (Schwertmann and Taylor, 1989; García-Balboa et al., 2011); therefore Fe $\mathrm{I}_{\text {siderite }}^{\mathrm{II}}$ was subtracted from $\mathrm{Fe}_{\mathrm{AOD}}$. Amorphous sulfides might also be dissolved for the same reason. Pohl (1962) and Rickard (2006) showed that solubility of FeS increased with decreasing $\mathrm{pH}$. Kostka and Luther (1994) revealed that AO-buffer could dissolve amorphous sulfides in marine and saltmarsh sediments. Therefore, $\mathrm{Fe}_{\mathrm{AVS}}$ was subtracted from $\mathrm{Fe}_{\mathrm{AOD}}$. Ferrozine mobilizes $\mathrm{Fe}^{\mathrm{II}}$ oxyhydroxides, e.g., green rust, and AOD extraction also dissolves green rust under anoxic conditions (Cornell and Schwertmann, 2007). van der Zee et al. (2002), working with Iberian continental margin sediments, showed that ferrozine did not react with $\mathrm{Fe}^{\mathrm{II}}$ minerals such as magnetite, monosulfide, siderite, and vivianite. Thus, $\mathrm{Fe}_{\text {ferrozine }}^{\mathrm{II}}$ was subtracted from $\mathrm{Fe}_{\mathrm{AOD}}$. Therefore, amorphous $\mathrm{Fe} \mathrm{III}^{\mathrm{II}}$ oxides reported here may be overestimated due to presence of siderite, amorphous sulfides and $\mathrm{Fe}^{\mathrm{II}}$ oxyhydroxides (e.g., green rust): all these minerals can be dissolved by AO-buffer, therefore the $\mathrm{Fe}^{\mathrm{II}}$ content of all these minerals was subtracted from $\mathrm{Fe}_{\mathrm{AOD}}$ to obtain $\mathrm{Fe}^{\mathrm{III}}$.

\section{Crystalline Fe ${ }^{\text {III }}$}

The crystalline $\mathrm{Fe}^{\mathrm{III}}$ was calculated using the following equation:

$$
\text { Crystalline } \mathrm{Fe}^{\mathrm{III}}=\mathrm{Fe}^{\mathrm{III}}-\text { Amorphous } \mathrm{Fe}^{\mathrm{III}}
$$

\section{$\mathrm{Fe}^{\text {II }}$}

The $\mathrm{Fe}^{\mathrm{II}}$ was calculated using the following equation:

$$
\mathrm{Fe}^{\mathrm{II}}=\mathrm{Fe}_{\text {Acc.M }}^{\mathrm{II}}+\mathrm{Fe}_{\text {Phyll }}^{\mathrm{II}}=\mathrm{Fe}(\text { total })-\mathrm{Fe}^{\mathrm{III}}
$$

\section{Crystalline Fe"}

The crystalline $\mathrm{Fe}^{\mathrm{II}}$ was calculated using the following equation:

$$
\text { Crystalline } \mathrm{Fe}^{\mathrm{II}}=\mathrm{Fe}_{\text {pyrite }}^{\mathrm{II}}+\mathrm{Fe}_{\text {vivianite }}^{\mathrm{II}}+\mathrm{Fe}_{\text {siderite }}^{\mathrm{II}}
$$

Crystalline $\mathrm{Fe}^{\mathrm{II}}$ comprised the $\mathrm{Fe}^{\mathrm{II}}$ in dominant $\mathrm{Fe}^{\mathrm{II}}$-bearing crystalline accessory minerals such as pyrite, vivianite, and siderite that were detected under our experimental conditions. Crystalline $\mathrm{Fe}^{\mathrm{II}}$ might be underestimated due to the possible existence of some minor crystalline accessory minerals that were not taken into account in our calculations.

\section{Amorphous Fe"}

The amorphous FeII was calculated using the following equation:

$$
\text { Amorphous } \mathrm{Fe}^{\mathrm{II}}=\mathrm{Fe}^{\mathrm{II}}-\text { Crystalline } \mathrm{Fe}^{\mathrm{II}}
$$

\section{MICROSCOPIC AND SPECTROSCOPIC ANALYSES}

To observe clay architectural patterns, whole (unmanipulated) MFT samples taken from column ports were cryo-fixed immediately using a cryogenic technique (Emitek K1250 cryogenic system) by plunging them into liquid $\mathrm{N}_{2}$. The frozen samples were transferred under vacuum to the cold-stage of the cryopreparation chamber for ice sublimation ( $10 \mathrm{~min}$ at pressure $10^{-5}$ Torr). After coating with gold, the samples were transferred into the cryo-SEM chamber, where they remained frozen during SEM imaging.

For conventional SEM and synchrotron XANES spectroscopy, a heavy liquid technique using a hydrophilic sodium polytungstenate solution of $\mathrm{Na}_{6}\left(\mathrm{H}_{2} \mathrm{~W}_{12} \mathrm{O}_{40}\right)$ with density $3 \mathrm{~g} \mathrm{~cm}^{-3}$ (Franke et al., 2007) was used to separate the heavy mineral fraction (density $>3 \mathrm{~g} \mathrm{~cm}^{-3}$ ). Approximately $5 \mathrm{~g}$ of MFT solids phase was dispersed in $20 \mathrm{~mL} \mathrm{Na}_{6}\left(\mathrm{H}_{2} \mathrm{~W}_{12} \mathrm{O}_{40}\right)$ solution with manual shaking in 50-mL centrifuge tubes. The suspension was centrifuged for $15 \mathrm{~min}$ at $3075 \mathrm{~g}$ to separate the light and heavy fractions.

For SEM analysis of the heavy fraction to examine mineralogy, samples were coated with carbon using an evaporative carbon coater (Leica EM SCD005). The samples were examined using SEM (JEOL-6301F) with field emission, equipped with a liquid $\mathrm{N}_{2}$-cooled lithium drifted silicon X-ray energy-dispersive spectrometer (PGT). XANES was performed to determine the Fe-bearing minerals present in the heavy fraction of the MFT solid phase using Fe K-edge $(E=7112 \mathrm{eV})$. The samples were mounted on Kapton tape (DuPont) and oriented at $45^{\circ}$ prior to $\mathrm{X}$-ray beam exposure at the VESPERS beamline in the Canadian Light Source synchrotron facility (Saskatoon, Canada). The scans ranged between $30 \mathrm{eV}$ below and above the absorption edge with a $0.5-\mathrm{eV}$ step size. At least five spectra were collected from each experimental sample and from the reference samples (standards of pure Fe minerals) used in the study. The standard minerals (analytical grade and natural minerals) were purchased from WARD Canada and Sigma-Aldrich (Canada). To avoid oxidation of $\mathrm{Fe}^{\mathrm{II}}$, strictly anoxic conditions were maintained throughout the entire process of sampling, transport, and preparation of the samples for XANES analysis.

\section{MICROBIAL CHARACTERIZATION BY PYROSEQUENCING}

The total genomic DNA was extracted from MFT samples using a physical lysis method described previously (Foght et al., 2004). Triplicate 300- $\mu$ l sub-samples were each extracted twice for a total of six extractions per sample. The precipitated DNA from the six extractions was pooled and used for PCR amplification. 
A negative control consisting of only extraction reagents was included with every set of samples to ensure contamination was not occurring at any stage of extraction.

After the negative extraction controls had been verified to contain no amplifiable DNA, each genomic DNA extract pool was PCR-amplified in triplicate $(3 \times 25 \mu \mathrm{L}$ reactions $)$ using the KAPA2G Robust HotStart DNA polymerase (Kapa Biosystems, Woburn MA). For every triplicate PCR reaction per sample, a negative PCR control was included containing only PCR reagents but no DNA template. Each $25-\mu \mathrm{L}$ reaction consisted of: $1 \mu \mathrm{L}$ of genomic DNA, $5 \mu \mathrm{L}$ of $5 \mathrm{X}$ KAPA2G Buffer A, $5 \mu \mathrm{L}$ of $5 \mathrm{X}$ KAPA Enhancer I, $1.25 \mu \mathrm{L}$ of $100 \%$ dimethylsulfoxide, $0.5 \mu \mathrm{L}$ of a $10 \mathrm{mM}$ dNTP mix, $2 \mu \mathrm{L}$ of $25 \mathrm{mM} \mathrm{MgCl}_{2}, 2.5 \mu \mathrm{L}$ of a $2.5 \mu \mathrm{M}$ working solution of forward primer, $2.5 \mu \mathrm{L}$ of a $2.5 \mu \mathrm{M}$ working solution of reverse primer, and $0.5 \mathrm{U}$ of the KAPA2G Robust HotStart DNA polymerase; all reagents were molecular biology grade. The universal primers target both Bacteria and Archaea (An et al., 2013). The forward primer 454T_FB has the 926Fw sequence (AAACTYAAAKGAATTGRCGG) at its $3^{\prime}$ end and a Badaptor sequence (CTATGCGCCTTGCCAGCCCGCTCAG) at its $5^{\prime}$ end. The reverse primer 454T_RL_X has the 1392R sequence (ACGGGCGGTGTGTRC) at its $3^{\prime}$ end, an L-adaptor sequence (CCATCTCATCCCTGCGTGTCTCCGAC) at its $5^{\prime}$ end and a sample-specific 10 nucleotide barcode sequence between adapter and primer, which allows for sample identification after multiplexing during pyrosequencing. The thermocycling program consisted of: one initial 5-min denaturation period at $95^{\circ} \mathrm{C} ; 10$ cycles of $\left(30 \mathrm{~s}\right.$ at $95^{\circ} \mathrm{C}, 30 \mathrm{~s}$ at $60^{\circ} \mathrm{C}$ decreasing by $0.5^{\circ} \mathrm{C} /$ cycle, and $30 \mathrm{~s}$ at $\left.72^{\circ} \mathrm{C}\right) ; 30$ cycles of $\left(30 \mathrm{~s}\right.$ at $95^{\circ} \mathrm{C}, 30 \mathrm{~s}$ at $55^{\circ} \mathrm{C}$, and $30 \mathrm{~s}$ at $72^{\circ} \mathrm{C}$ ); and one final $5 \mathrm{~min}$ extension period at $72^{\circ} \mathrm{C}$.

Triplicate PCR products from each sample were pooled and an aliquot was examined for quality control by electrophoresis on an agarose gel (i.e., single band of expected size). PCR products were then purified using a QIAquick PCR purification kit (Qiagen) according to the manufacturer's instructions. Purified PCR products were quantified in duplicate using the Nanodrop 2000c (Thermo Scientific) and diluted to $25 \mathrm{ng} \mu \mathrm{L}^{-1}$. Diluted and purified PCR products were again quantified using Nanodrop and visually verified on an agarose gel before being sent to Genome Quebec Innovation Centre, Montreal, QC, Canada for pyrosequencing using a GS FLX Titanium Series XLR70 kit (Roche Diagnostics Corporation). Raw pyrosequencing data were analyzed using Phoenix 2, an in-house developed SSU rRNA data analysis pipeline providing quality control and chimera detection, following the procedure described by Soh et al. (2013). Pyrotag sequences $(\sim 7000-10,000$ reads per sample) have been submitted to the NCBI Short Read Archive (http://www.ncbi.nlm. nih.gov/sra) under accession numbers SRR621691-SRR621697 representing, respectively: initial, $\mathrm{U} 1, \mathrm{U} 2, \mathrm{U} 3, \mathrm{~A} 1, \mathrm{~A} 2$, and A3 samples. Quality-verified sequences were compared against the SILVA 102 database (http://www.arb-silva.de) and clustered into Operational Taxonomic Units (OTUs) at 5\% distance. OTUs with read abundance $<1 \%$ in every sample were not considered further in community analysis; hence the total abundance reported is $<100 \%$. To compare communities in samples, non-metric multidimensional scaling (NMDS) analysis was implemented in Phoenix 2.

\section{RESULTS}

\section{REDOX CONDITIONS, Fe FRACTIONATION AND MINERALOGY}

Previous small-scale (2-L) experiments demonstrated that stimulating indigenous microbes in MFT with labile organic carbon sources enhanced clay consolidation and pore water recovery (Bressler et al., 2010). In the current experiment we used larger volumes of MFT ( $45 \mathrm{~L})$ to reduce "wall effects" in the columns, and low concentrations of water-soluble canola meal hydrolysate as an organic carbon source. A parallel unamended MFT control column showed the effects of microbial metabolism of endogenous carbon (e.g., residual hydrocarbons and their metabolites; Siddique et al., 2007). The stationary acrylic columns containing amended or unamended MFT were incubated at $\sim 20^{\circ} \mathrm{C}$ (circa in situ temperature in the tailings ponds) under a $\mathrm{N}_{2}$ headspace to maintain anaerobic conditions. As described in a companion paper (Siddique et al., 2014), the MFT underwent bioconsolidation and de-watering measured, respectively, as a decrease in the height of the mudline (the interface between solids and overlying expressed porewater) and an increase in the volume of "cap water" above the mudline; this bioconsolidation was more pronounced in the amended than the unamended MFT column. Three ports in the sides of each column allowed access for measurements and sample collection; Port 1 in each column accessed the cap water whereas Ports 2 and 3 accessed tailings below the mudline; the latter MFT samples comprised porewater (described in the companion paper) and solid phase, described herein.

Methanogenic conditions prevailed in the amended column during incubation, as inferred from the composition of biogenic gas emitted and trapped: by 75 days, amended MFT had generated $2.8 \mathrm{~L}_{\text {of }} \mathrm{CH}_{4}$ and $\sim 0.5 \mathrm{~L} \mathrm{CO}_{2}$ in the column headspace vs. negligible gas emissions from unamended MFT (Siddique et al., $2014)$. We did not determine the redox potential $\left(E_{h}\right)$ of the tailings during incubation because sampling would have disturbed the MFT structure, but we did measure $E_{h}$ when samples were withdrawn at 213 days. Samples from the amended column were more reduced, where $\mathrm{E}_{\mathrm{h}}$ ranged from $-33 \mathrm{mV}$ in cap water to $-350 \mathrm{mV}$ at port 3 (Figure 2) vs. the unamended column where suboxic conditions $\left(E_{h} 209 \mathrm{mV}\right.$ ) prevailed in the cap water while the MFT below the mudline experienced anoxic conditions with $\mathrm{E}_{\mathrm{h}}$ of -148 at port 3 (Figure 2).

Because the surface properties of clays are of paramount importance for fines consolidation, minerals in the solids phase of amended and unamended MFT samples collected at Ports 2 and 3 were characterized and quantified. Fractionation and quantitation of Fe in the solid phase is important for inferring its role in microbial metabolism under methanogenic conditions and also for observing transformation (dissolution and precipitation) of minerals under reducing conditions. The forms of Fe in the initial MFT before any manipulation are shown in Table 1. Fe fractionation of the solid phase of unamended and amended MFT samples after 213 days of incubation (Figure 3A) was calculated from the data shown in Table 2 using the approaches described in Materials and Methods. In unamended MFT, $\mathrm{Fe}^{\mathrm{III}}$ and $\mathrm{Fe}^{\mathrm{II}}$ were present in almost equal concentrations and in crystalline form. Oxyhydroxides were major forms of crystalline $\mathrm{Fe}^{\mathrm{III}}$ whereas crystalline $\mathrm{Fe}^{\mathrm{II}}$ comprised pyrite $\left(\mathrm{FeS}_{2}\right)$, siderite $\left(\mathrm{FeCO}_{3}\right)$, and vivianite $\left[\mathrm{Fe}_{3}\left(\mathrm{PO}_{4}\right)_{2} .8 \mathrm{H}_{2} \mathrm{O}\right]$. 


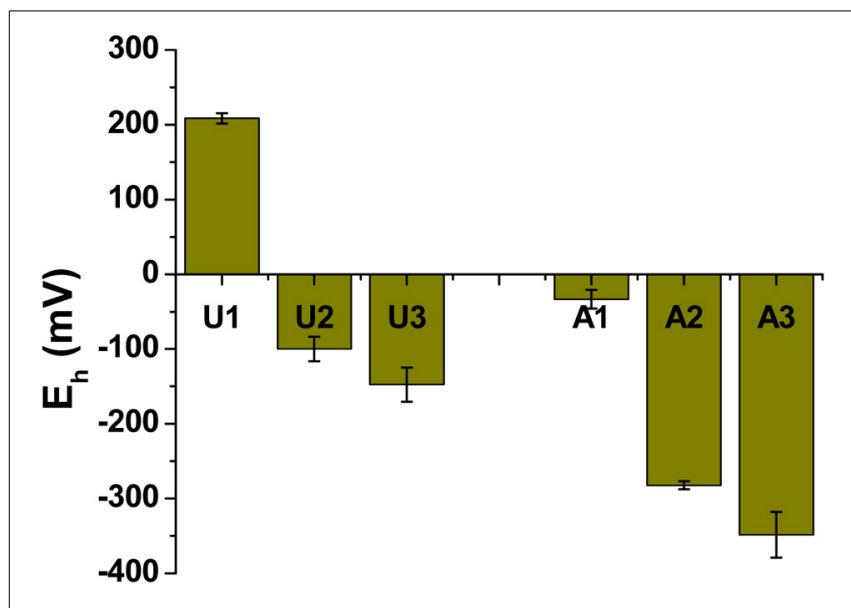

FIGURE 2 | Redox potential $\left(E_{h}\right)$ in unamended $(U)$ and amended (A) MFT. Measurements were taken from port 1 (cap water; see Figure 1 in Siddique et al., 2014) and ports 2 and 3 (solids) after 213 days incubation. Bars represent the mean values from analyses of triplicate samples taken from each column and error bars represent 1 standard deviation.

\section{Table 1 | Fractionation of iron (Fe) in MFT prior to amendment and incubation.}

\begin{tabular}{|c|c|}
\hline Fe fractions $(w t \%)^{a}$; number of replicates & Value \\
\hline Total Fe ${ }^{1}$ in solid phase; $n=2$ & $2.24 \pm 0.13$ \\
\hline $\mathrm{Fe}^{\| 2}$ in solid phase; $n=3$ & $0.48 \pm 0.02$ \\
\hline Fe-DCB ${ }^{3}$ in solid phase; $n=2$ & $1.53 \pm 0.04$ \\
\hline Fe-AOD 4 in solid phase; $n=2$ & $1.11 \pm 0.11$ \\
\hline $\mathrm{AVS}^{5}$ in whole MFT; $n=2$ & $0.05+0.00$ \\
\hline Cr-R sulfides ${ }^{6}$ in whole MFT; $n=3$ & $0.34+0.05$ \\
\hline Iron related $\mathrm{P}$ in whole $\mathrm{MFT} ; n=4$ & $0.018+0.001$ \\
\hline
\end{tabular}

See Materials and Methods section for detailed description of fractions and analyses.

${ }^{a}$ Calculations were performed on oven dry weight basis.

1 Total iron ("environmentally available") after acid digestion (US EPA, 2007).

2 Ferrozine extractable $\mathrm{Fe}^{\prime l}$ in solid phase.

${ }^{3}$ Dithionite-citrate-bicarbonate extractable iron.

${ }^{4}$ Ammonium oxalate extractable iron.

${ }^{5}$ Acid volatile sulfides content.

${ }^{6}$ Cr-reducible sulfides content.

Synchrotron analyses (XANES; Figure 4) revealed that ferrihydrite $\left(5 \mathrm{Fe}_{2} \mathrm{O}_{3} \cdot 9 \mathrm{H}_{2} \mathrm{O}\right)$ and goethite $(\alpha-\mathrm{FeOOH})$ were dominant $\mathrm{Fe}^{\mathrm{III}}$ minerals, whereas siderite was the dominant $\mathrm{Fe}^{\mathrm{II}}$ mineral in both amended and unamended MFT (Table 3). During incubation and microbial metabolism in amended MFT, Fe ${ }^{\mathrm{III}}$ decreased and $\mathrm{Fe}^{\mathrm{II}}$ increased, with amorphous $\mathrm{Fe}^{\mathrm{II}}$ as the dominant phase. Chemical analyses showed that amorphous FeS and crystalline vivianite increased in amended MFT whereas the concentration of pyrite remained unchanged (Figure 3B). These analyses indicate that significant transformation of iron minerals occurred in the amended MFT during incubation, concomitant with consolidation, de-watering, and gas production (Siddique et al., 2014).

\section{CLAY ARCHITECTURE}

The greater recovery of porewater from amended vs. unamended MFT (Siddique et al., 2014) led us to use cryo-SEM to examine the solid phase and determine the clay architecture of MFT samples collected at 213 days of incubation (Figure 5). Microscopy revealed aggregation of clay particles in the amended MFT, producing networks of pores between aggregates that presumably would facilitate egress of pore water and biogenic gas from MFT (Figure 5B), compared with the fine pore structure preserved in the unamended MFT (Figure 5A). Newly transformed amorphous Fe minerals coated the charged clay surfaces in the amended MFT and the coatings observed on aggregate surfaces in amended MFT (Figure 5D) were even more apparent using conventional SEM (Figure 5F). Energy dispersive spectroscopy (EDS) analyses performed during cryo-SEM confirmed that the clay aggregates in amended MFT were coated with amorphous Fe minerals (Figure 5H) that, according to mineralogical analyses described above (Figure 3, Table 3), were newly formed by transformation of crystalline iron minerals during incubation. In the unamended MFT, clay particles were observed randomly oriented and closely stacked, without any Fe coating (Figures 5A,C,E,G). These observations imply that transformation of iron minerals has changed the clay surfaces, allowing them to create larger pore structures stabilized by formation of new minerals.

\section{MICROBIAL COMMUNITY STRUCTURE}

To understand electron flow from labile organic carbon to $\mathrm{Fe}^{\mathrm{III}}$ minerals in MFT via indigenous microorganisms, 16S rRNA gene pyrosequencing was performed. NMDS analysis was performed on the total communities in initial MFT (before manipulation) and in unamended and amended MFT samples taken from Port 1 (the water cap) and Ports 2 and 3 (tailings below the mud line) after 213 days incubation. Figure 6A shows that the unamended tailings communities were most similar to the initial MFT, whereas the amended tailings communities and both cap water communities differed from the original tailings communities and from each other.

The microbial community initially present in MFT before manipulation comprised a majority of methanogens $(\sim 65 \%$ of pyrosequences) dominated by putative hydrogenotrophs (43\% Methanolinea/Methanoregula), with fewer acetoclastic methanogen sequences ( $\sim 20 \%$ Methanosaeta) (Figure 6B). The bacterial component included Betaproteobacteria (family Comamonadaceae; $9 \%$ ) and Chloroflexi (4\%) as dominant phyla, with minor contributions by diverse bacterial taxa. After 213 days incubation, the community in unamended tailings below the mudline (Ports 2 and 3 ) still closely resembled the initial MFT community. However, Port 1 in the unamended column accessed the expressed pore water that collected above the mudline. The community structure of that cap water had shifted radically, being virtually depleted of methanogens but enriched in anaerobic Bacteroidetes (order Sphingobacteriales) and in Alphaand Gammaproteobacteria, which include numerous facultative anaerobes. The proportion of reads assigned to "rare" taxa (each with abundance $<1 \%$ ) comprised nearly $40 \%$ of total reads, with virtually all being bacterial. 


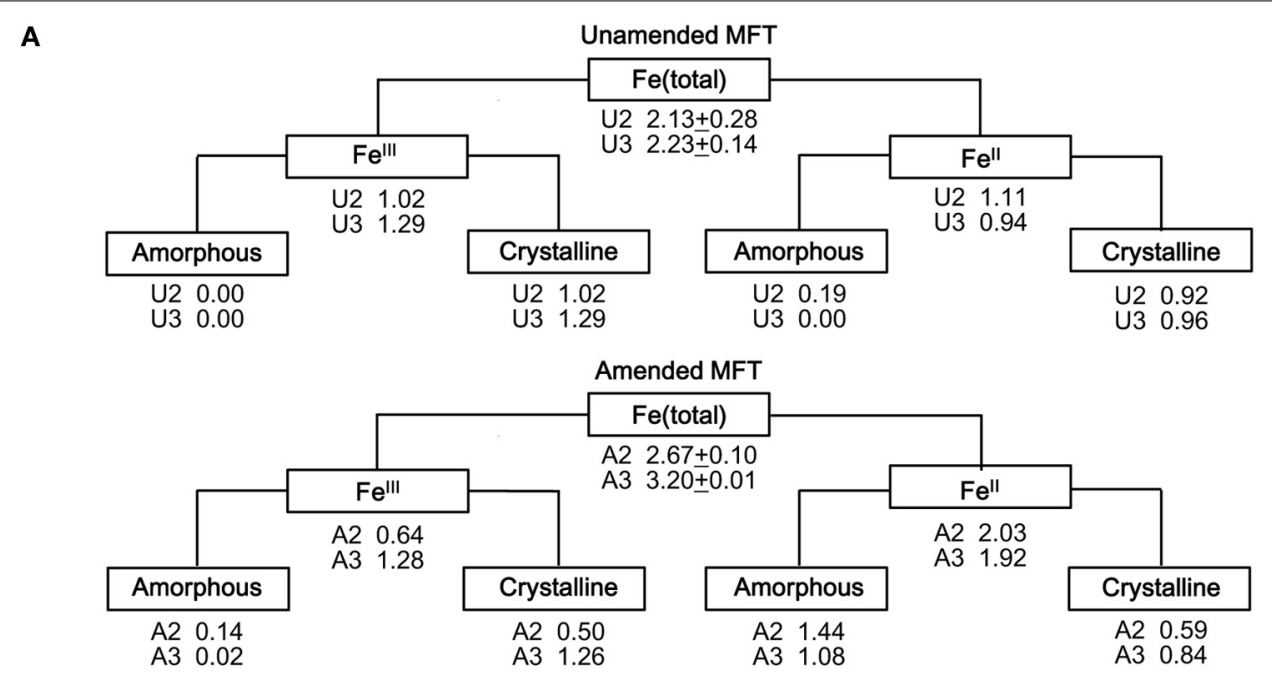

B
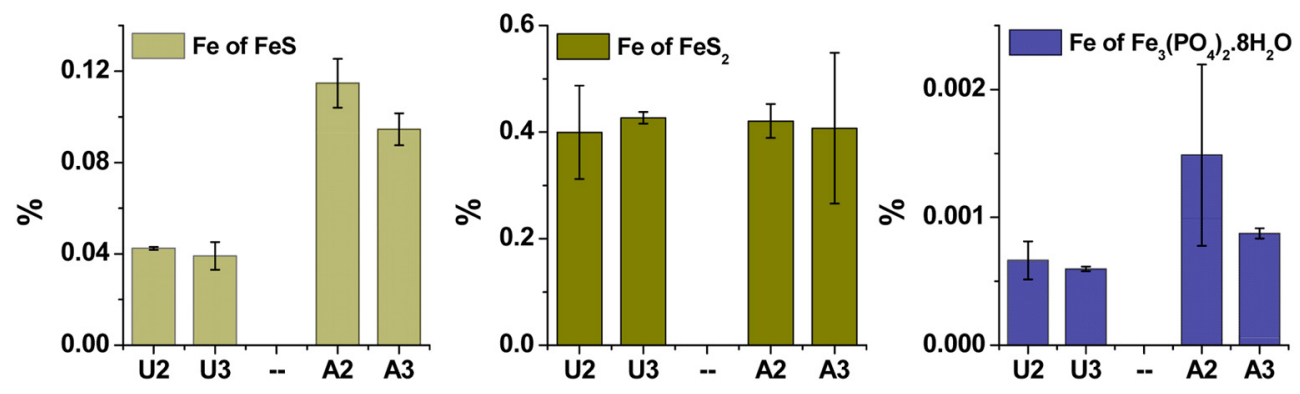

FIGURE 3 | Iron (Fe) transformation observed in unamended (U) and amended (A) MFT at $\mathbf{2 1 3}$ days incubation. Labels A2 through U3 designate the columns and ports used to withdraw MFT samples below the mudline. (A) Fe fractionation (Table 2) calculated in \% (oven dry basis): Fe (total) = Fe (acid digested $\mathrm{Fe}$ ); Fe $\mathrm{Fe}^{\mathrm{II}}=\mathrm{Fe}$ (dithionite-citrate-bicarbonate; $\left.\mathrm{DCB}\right)-\mathrm{Fe}^{\| I}$ (ferrozine); Fe ${ }^{\text {III }}$ (amorphous) = Fe (ammonium oxalate extraction; AOD) - Fe" (siderite) - Fe (acid volatile sulfides; AVS) - Fe (ferrozine); Fe ${ }^{\prime \prime \prime}$
$($ crystalline $)=\mathrm{Fe}^{\text {III }}-\mathrm{Fe}^{\mathrm{III}}$ (amorphous); $\mathrm{Fe}^{\text {II }}=\mathrm{Fe}$ (total) $-\mathrm{Fe}^{\mathrm{III}} ; \mathrm{Fe}^{\text {II }}$ $($ crystalline $)=\mathrm{Fe}$ (pyrite) + Fe (vivianite) + Fe (siderite); and Fe" (amorphous) $=\mathrm{Fe}^{\|}-\mathrm{Fe}^{\|}$(crystalline). Standard deviations for Fe (total) represent duplicate samples. (B) Fe associated with newly formed Fe"l minerals (amorphous sulfide [FeS], pyrite $\left[\mathrm{FeS}_{2}\right]$, and vivianite $\left[\mathrm{Fe}_{3}\left(\mathrm{PO}_{4}\right)_{2} \cdot 8 \mathrm{H}_{2} \mathrm{O}\right]$ ). Bars represent means of triplicate samples and error bars represent 1 standard deviation.
The microbial community detected in amended MFT solids also shifted during incubation, compared to the initial and the unamended solids. Fewer hydrogenotrophic methanogen sequences (Methanolinea and Methanoregula) resulted in a lower proportion of total methanogenic sequences, but the proportion of acetoclasts (Methanosaeta) was almost unchanged (Figure 6B). Among bacterial sequences, the diversity and abundance of Clostridiales (particularly Anaerobacter) and Synergistaceae (including Thermanaerovibrio) increased significantly in amended vs. initial and unamended MFT (Table 4), likely reflecting increased fermentation of the hydrolyzed canola meal amendment. In contrast, betaproteobacterial sequences (mainly in the family Comamonadaceae) decreased in amended MFT solids compared to initial MFT. The community in cap water overlying amended MFT diverged substantially from the MFT solids with a precipitous decline of archaeal sequences that were replaced by sequences affiliated with the uncharacterized, uncultivated candidate division W6. Sequences of the order Sphingobacteriales and little-known class Lentisphaeria also increased in abundance. The "rare" microbiome (each $<1 \%$ abundance) comprised about one-third of the total pyrosequences. Thus, amendment shifted the MFT solids community slightly toward fermenters while retaining a substantial proportion of methanogens ( $>40 \%)$, but expression of pore water radically altered the community structure to become more diverse, no longer resembling the solids-associated community.

\section{DISCUSSION}

In a companion paper we described how microbial activity in oil sands tailings, including methanogenesis, promoted rapid consolidation of clay particles, (Siddique et al., 2014). Pathway I (Figure 1) proposes that the indigenous microbial tailings community alters pore water chemistry by producing $\mathrm{CO}_{2}$, which dissolves in pore water and lowers its $\mathrm{pH}$. The decrease in pore water $\mathrm{pH}$ increases dissolution of carbonate minerals, which increases the ionic strength of the porewater. This in turn reduces the diffuse double layer (DDL) of clay particles and enhances consolidation of oil sands tailings. The other important and 
Table 2 | Iron (Fe) fractionation of unamended and amended MFT after 213 days incubation.

\begin{tabular}{|c|c|c|c|c|}
\hline Fe fractions $(w t \%)^{a}$; number of replicates & U2* & U3* & $\mathbf{A} 2^{*}$ & A3* \\
\hline $\mathrm{Fe}^{112}$ in solid phase; $n=3$ & $0.28 \pm 0.09$ & $0.47 \pm 0.04$ & $0.30 \pm 0.04$ & $0.21 \pm 0.02$ \\
\hline Fe-AOD ${ }^{4}$ in solid phase; $n=2$ & $0.80 \pm 0.05$ & $0.88 \pm 0.03$ & $0.72 \pm 0.10$ & $0.75 \pm 0.03$ \\
\hline Fe of $\mathrm{FeS}^{5} ; n=2$ & $0.042 \pm 0.001$ & $0.039 \pm 0.006$ & $0.115 \pm 0.011$ & $0.095 \pm 0.007$ \\
\hline Fe of pyrite ${ }^{6} ; n=3$ & $0.399 \pm 0.087$ & $0.427 \pm 0.011$ & $0.421 \pm 0.032$ & $0.407 \pm 0.142$ \\
\hline Fe, related to phosphorus $8 ; n=3$ & $0.00066 \pm 0.00015$ & $0.00060 \pm 0.00002$ & $0.00149 \pm 0.00071$ & $0.00087 \pm 0.00004$ \\
\hline
\end{tabular}

The data presented here were used to construct Figure 3.

*U2: port 2, unamended column; U3: port 3, unamended column; A2: port 2, amended column; A3: port 3, amended column.

${ }^{1}$ Total iron (US EPA, 2007).

${ }^{2}$ Ferrozine-extractable $\mathrm{Fe}$ "l in solid phase.

${ }^{3}$ Dithionite-citrate-bicarbonate extractable iron.

${ }^{4}$ Ammonium oxalate-extractable iron.

${ }^{5} \mathrm{Fe}$ "l of amorphous sulfides was calculated from AVS content shown in Table 1.

${ }^{6} \mathrm{Fe}^{\prime l}$ of pyrite was calculated from Cr-reducible sulfides and AVS content.

${ }^{7} \mathrm{Fe}$ ll of carbonates $\left(\mathrm{FeCO}_{3}\right)$ was calculated after subtracting $\mathrm{CaCO}_{3}$ and $\mathrm{MgCO}_{3}$ from total carbonates and using stoichiometric ratios.

${ }^{8} \mathrm{Fe}$ "l of phosphates (vivianite) was calculated from iron related to phosphorus.

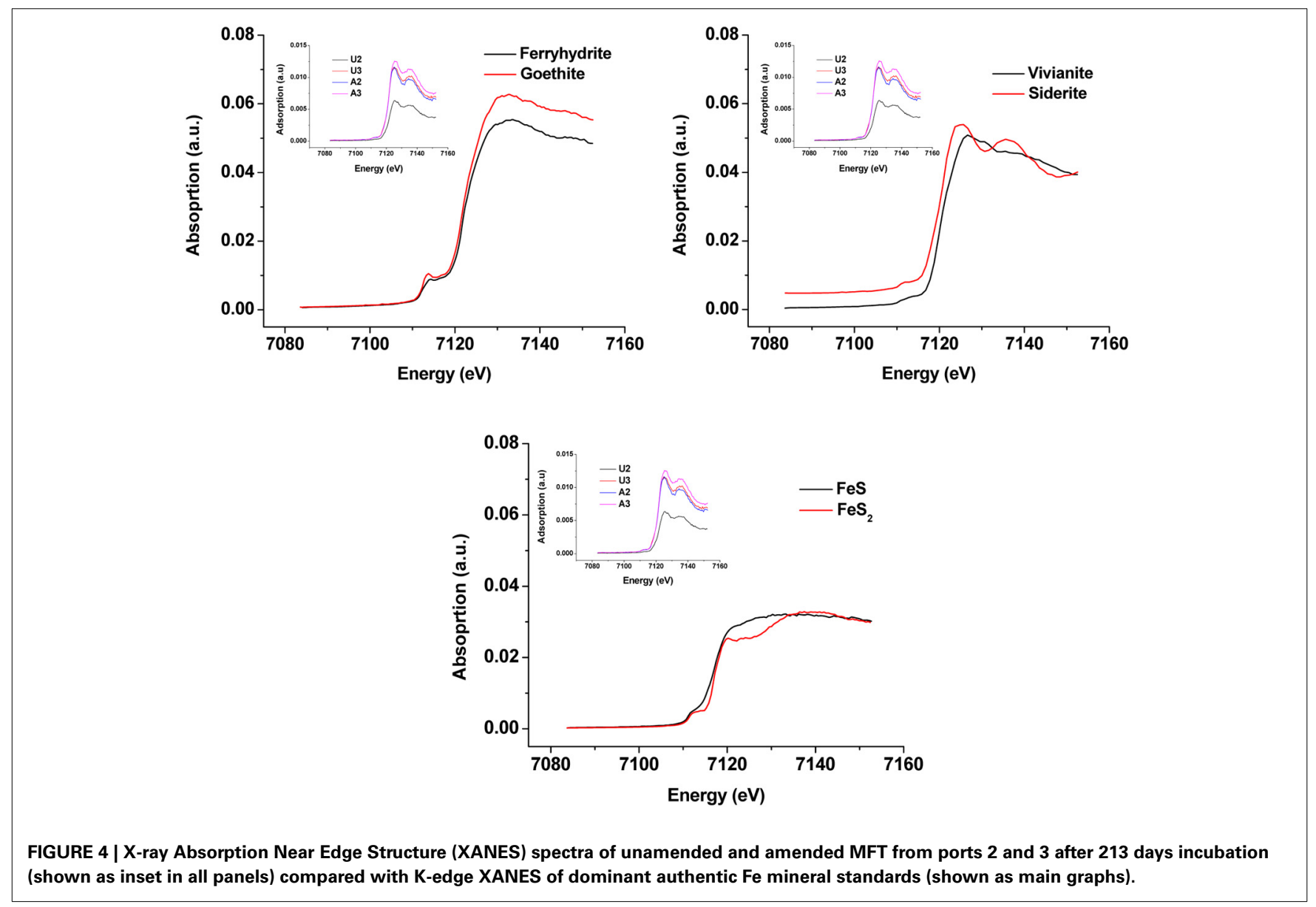


Table 3 | Qualitative and semi-quantitative analyses of major iron minerals in unamended and amended MFT after 213 days incubation, determined using K-edge XANES spectra compared with 12 commercial iron mineral standards.

\begin{tabular}{|c|c|c|c|c|}
\hline Major iron minerals & U2* & U3* $^{*}$ & A2* & A3* \\
\hline Ferrihydrite $[\mathrm{Fe}(\mathrm{OH}) \mathrm{O}]^{\dagger}$ & +++ & ++ & ++ & +++ \\
\hline Goethite $[\mathrm{Fe}(\mathrm{OH}) \mathrm{O}]^{\dagger}$ & +++ & ++ & ++ & +++ \\
\hline Siderite $\left[\mathrm{FeCO}_{3}\right]^{\dagger}$ & +++ & +++ & ++++ & +++ \\
\hline Vivianite $\left[\mathrm{Fe}_{3}\left(\mathrm{PO}_{4}\right)_{2}\right]^{\dagger}$ & ++ & ++ & ++ & ++ \\
\hline Pyrite $\left[\mathrm{FeS}_{2}\right]^{\dagger}$ & + & + & + & + \\
\hline $\mathrm{FeS}^{\S}$ & + & + & + & + \\
\hline Hematite $\left[\mathrm{Fe}_{2} \mathrm{O}_{3}\right]^{\dagger}$ & - & - & - & - \\
\hline Magnetite $\left[\mathrm{Fe}_{3} \mathrm{O}_{4}\right]^{\dagger}$ & - & - & - & - \\
\hline $\mathrm{FeO}^{\S}$ & - & - & - & - \\
\hline $\mathrm{Fe}_{3} \mathrm{O}_{4}^{\S}$ & - & - & - & - \\
\hline $\mathrm{Fe}_{2} \mathrm{O}_{3}^{\$}$ & - & - & - & - \\
\hline $\mathrm{FeCl}_{2}^{\S}$ & - & - & - & - \\
\hline
\end{tabular}

Athena software (IFEFFIT library for XAFS analysis) was used to perform linear combination fit. Number of + symbols represents estimated relative proportions of minerals. Discrimination among different $\mathrm{Fe}^{\mathrm{III}}$ oxyhydroxides is difficult using XANES (Prietzel et al., 2007).

*U2: port 2, unamended column, U3: port 3, unamended column, A2: port 2, amended column, A3: port 3, amended column.

${ }^{\dagger}$ Research minerals (Ward's Science Canada).

${ }^{\S}$ Reagent grade chemicals (Sigma-Aldrich, Fisher Scientific).

direct biogeochemical mechanism influencing consolidation of oil sands tailings is microbial reduction of $\mathrm{Fe}^{\mathrm{III}}$ minerals (Pathway II; Figure 1), discussed in the current study. Pathway II invokes microbial reduction of Fe minerals in amended MFT during organic carbon metabolism under methanogenic conditions.

Fe undergoes redox transformation processes linked to microbial metabolism (Roden, 2012). Comparing Fe fractionation in amended and unamended MFT after 213 days of incubation, we observed that microbial metabolism transformed $\mathrm{Fe}^{\mathrm{III}}$ minerals so that more amorphous $\mathrm{Fe}^{\mathrm{II}}$ minerals appeared in amended MFT. Chemical analyses showed that amorphous FeS and crystalline vivianite increased in amended MFT. Because amorphous FeS constitutes only $10-14 \%$ of total amorphous $\mathrm{Fe}^{\mathrm{II}}$ in amended MFT, we propose that goethite and ferrihydrite transformed into green rust (mixed-valence $\mathrm{Fe}^{\mathrm{II}}-\mathrm{Fe}^{\mathrm{III}}$ hydroxides, carbonates and/or sulfates), part of which was further transformed into other $\mathrm{Fe}^{\mathrm{II}}$ minerals such as sulfides, siderite, and vivianite. Green rust is a mixed-valence amorphous $\mathrm{Fe}^{\mathrm{II}}-\mathrm{Fe}^{\mathrm{III}}$ mineral. Jiang et al. (2013) revealed that $\mathrm{Fe}^{\mathrm{III}}$ mineral was transformed to soluble $\mathrm{Fe}^{\mathrm{II}}$ that was re-adsorbed and re-precipitated as $\mathrm{Fe}^{\mathrm{III}}$ after donating electrons to methanogens during $\mathrm{CH}_{4}$ production. Owing to the great variation in the composition of green rust (Cornell and Schwertmann, 2007) and unavailability of a suitable chemical method to analyze it, we did not quantify green rust in MFT but speculate on its occurrence based on mass balance calculations and observations in other systems where goethite and ferrihydrite transformation occurred, forming the green rust minerals fougerite $\left[\mathrm{Fe}_{2}^{\mathrm{II}} \mathrm{Fe}^{\mathrm{III}}(\mathrm{OH})_{7}\right]$ in fresh water and GR2 $\left[\mathrm{Fe}_{4}^{\mathrm{II}} \mathrm{Fe}_{2}^{\mathrm{III}}(\mathrm{OH})_{12} \mathrm{SO}_{4}\right]$ in sea water at pH 7-9 (Rickard and
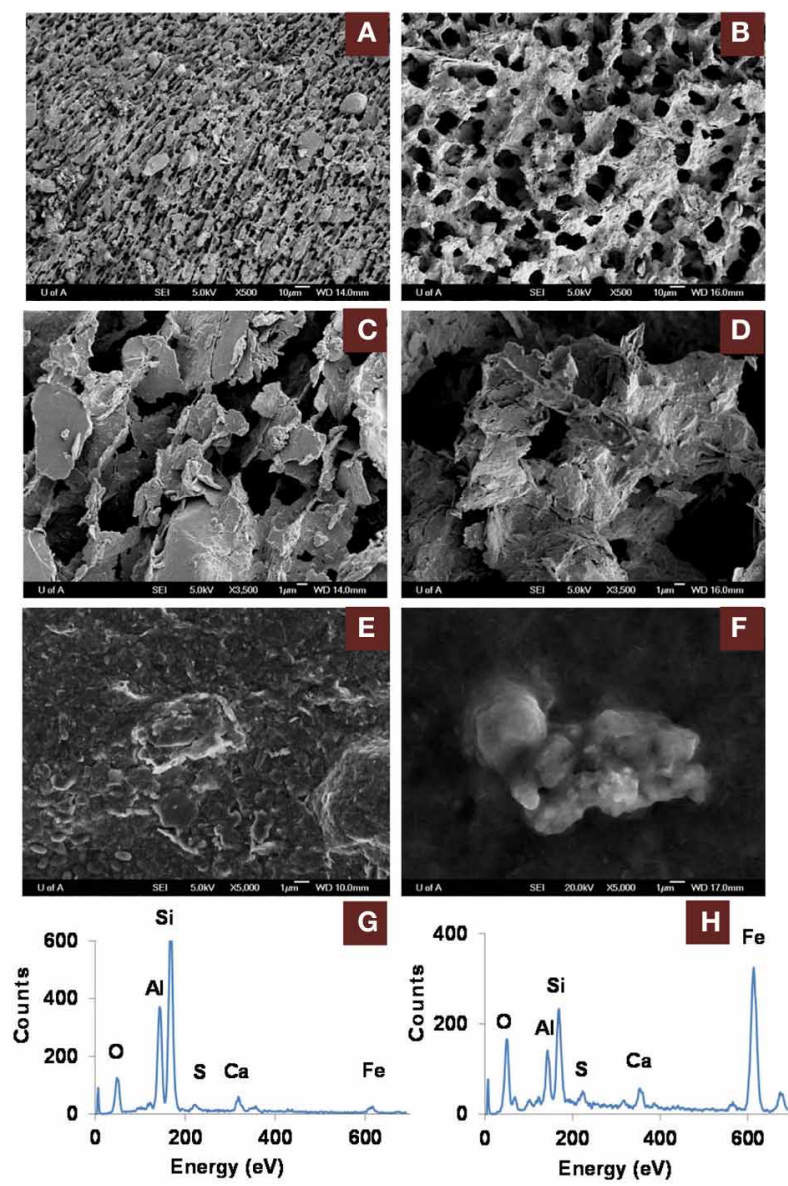

FIGURE 5 | Scanning electron microscope (SEM) micrographs of clay architecture in amended and unamended MFT at 213 days incubation. (A-D), cryo-SEM; (E,F), conventional SEM. (A) Unamended MFT with random clay particle structure; scale bar $10 \mu \mathrm{m}$. (B) Canola-amended MFT with flocculated clay particles (light) having card-house structure, producing a network of interstitial pores (dark); scale bar $10 \mu \mathrm{m}$. (C) Phyllosilicate particles in unamended MFT, lacking transformed mineral coating; scale bar $1 \mu \mathrm{m}$. (D) Phyllosilicate particles in amended MFT, forming aggregates with amorphous surface coating; scale bar $1 \mu \mathrm{m}$. (E) Weakly aggregated phyllosilicate particles in unamended MFT. (F) Aggregated phyllosilicate particles in amended MFT. (G) Energy dispersive spectrum (EDS) of (E) showing phyllosilicates with negligible iron mineral coating. (H) EDS of (F) revealing phyllosilicates coated with amorphous iron minerals.

Luther, 2007). However, we cannot exclude contributions from abiotic $\mathrm{Fe}^{\mathrm{III}}$ reduction because $\mathrm{Fe}^{\mathrm{II}}$ also catalyzes reduction and dissolution of Fe $\mathrm{III}^{\mathrm{II}}$ minerals (Suter et al., 1988; Kostka and Luther, 1994), including ferrihydrite and goethite transformation into mixed Fe $\mathrm{II}^{\mathrm{II}}-\mathrm{Fe}^{\mathrm{III}}$ green rust at pH 6.3 (Usman et al., 2012).

Formation of $\mathrm{Fe}^{\mathrm{II}}$ minerals such as sulfides, siderite, and vivianite in amended MFT occurred either through transformation of green rust group minerals, which are considered the most significant precursors (Fe source) of sulfide minerals (Rickard and Luther, 2007), or directly through dissolved species such as $\mathrm{Fe}^{\mathrm{II}}\left(\mathrm{Fe}^{2+}\right)$, sulfide $\left(\mathrm{S}^{2-}, \mathrm{HS}^{-}\right), \mathrm{CO}_{3}^{2-}$ and $\mathrm{PO}_{4}^{3-}$ where $\mathrm{Fe}^{2+}$ and $\mathrm{S}^{2-}$ were produced during microbial reduction of $\mathrm{Fe}^{\mathrm{III}}$ minerals and $\mathrm{SO}_{4}^{2-}$, respectively. The MFT contained low concentrations of 

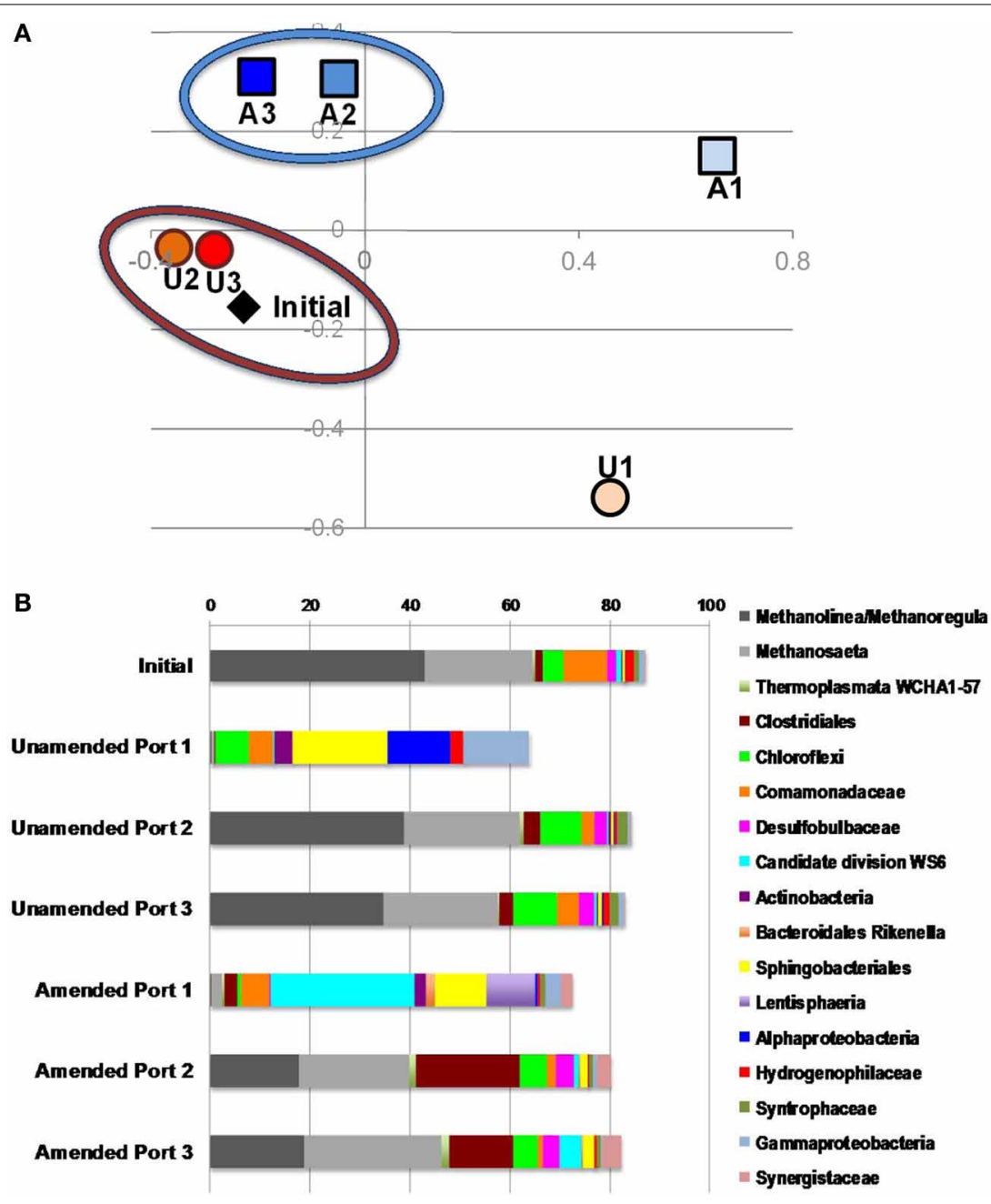

FIGURE 6 | Microbial community analysis. (A) Non-metric multidimensional scaling (NMDS) analysis of $16 \mathrm{~S}$ rRNA gene pyrosequences comprising microbial communities in initial MFT (black diamond) and MFT samples taken from unamended ( $U$; orange circles) and amended ( $\mathrm{A}$; blue squares) column ports. Numbers indicate the ports (Figure 1 in Siddique et al., 2014), with port 1 accessing cap water and ports 2 and 3 accessing MFT in both columns. (B) Microbial community composition in the initial bulk MFT, cap water (port 1) and tailings (ports 2 and 3 ) in the unamended and amended MFT after 213 days incubation, based on 16S rRNA gene pyrosequencing. Only OTUs present at an abundance of $\geq 1 \%$ in one or more communities were considered; hence the total community is $<100 \%$.
$\mathrm{SO}_{4}^{2-}$ (for FeS precipitation) and $\mathrm{PO}_{4}^{3-}$ (for vivianite formation) but more $\mathrm{HCO}_{3}^{-}$was available for siderite formation [Table 1 and Figure 6; (Siddique et al., 2014)]. We did not detect $\mathrm{Fe}^{2+}$ in porewater or on clay surfaces in any columns using the described methods. Therefore, we postulate that Pathway IIA (Figure 1) does not contribute significantly to the consolidation of tailings but that $\mathrm{Fe}^{2+}$ was converted to $\mathrm{Fe}^{\mathrm{II}}$ minerals that entrapped clay particles (Pathway IIB).

Molecular analysis of microbial communities in MFT samples suggests that Fe transformation in amended MFT was not carried out by canonical Fe-reducing bacteria. Microbial communities in amended MFT comprised $\sim 50 \%$ methanogens with a slightly higher proportion of acetoclastic methanogens (Methanosaeta). Among the bacterial sequences that constituted $~ 50 \%$ of microbial communities, the abundance of members of the order Clostridiales and family Synergistaceae increased significantly in amended vs. initial and unamended MFT. Microbial characterization led us to propose a microbially-mediated $\mathrm{Fe}^{\mathrm{III}}$-reduction pathway (Figure 7) in which Clostridiales and Synergistaceae ferment organic carbon in amended MFT to produce simple fatty acids, alcohols, $\mathrm{CO}_{2}$, and $\mathrm{H}_{2}$ as substrates for sulfate-reducing bacteria (SRB) such as Desulfobulbaceae, and for methanogens via syntrophic interactions. Fermenters do not completely oxidize fermentable substrates to $\mathrm{CO}_{2}$ when $\mathrm{Fe} \mathrm{III}^{\mathrm{II}}$ is the sole electron acceptor but they can divert a portion of the electrons from fermentation to $\mathrm{Fe}^{\mathrm{III}}$ as an electron sink or supplementary electron acceptor without conserving sufficient energy for cell growth (Coleman et al., 1993; Dobbin et al., 1999). Other studies support these observations, with Clostridiales and Desulfobulbaceae being involved in $\mathrm{Fe}^{\mathrm{III}}$-reduction during benzene degradation (Kunapuli et al., 2007). Jiang et al. (2013) reported that syntrophic acetate-oxidizing Clostridia oxidized acetate to $\mathrm{HCO}_{3}^{-}$and $\mathrm{H}^{+}$, 
Table 4 | Relative abundance of 16S rRNA gene pyrosequences affiliated with the bacterial orders Clostridiales and Synergistales in MFT samples prior to amendment and in amended and unamended MFT after 213 days incubation.

\begin{tabular}{|c|c|c|c|c|c|c|c|}
\hline \multirow[t]{2}{*}{ Nomenclature } & \multirow[t]{2}{*}{ Initial } & \multicolumn{6}{|c|}{ Sample port } \\
\hline & & U1 & U2 & U3 & A1 & A2 & A3 \\
\hline Synergistales; Synergistaceae & $-^{*}$ & - & - & - & 1.3 & 0.8 & 0.6 \\
\hline Synergistales; Synergistaceae; Thermanaerovibrio & 0.1 & - & 0.2 & 0.2 & 0.8 & 2.3 & 3.3 \\
\hline Synergistales; Synergistaceae & - & - & - & - & 0.3 & 0.3 & 0.3 \\
\hline Clostridiales & - & - & - & 0.1 & 0.8 & 0.8 & 1.1 \\
\hline Clostridiales; Family_XI_Incertae_Sedis & 0.3 & - & 0.4 & 0.1 & - & 1.9 & 1.7 \\
\hline Clostridiales; Family_XI_Incertae_Sedis; Sedimentibacter & - & - & - & - & - & 0.7 & 0.5 \\
\hline Clostridiales; Clostridiaceae; Acidaminobacter & - & - & - & - & - & 0.8 & 0.5 \\
\hline Clostridiales; Family_XII_Incertae_Sedis; Fusibacter & - & - & - & - & - & - & 0.2 \\
\hline Clostridiales; Family_XIII_Incertae_Sedis & - & - & - & - & 0.2 & 0.1 & 0.2 \\
\hline Clostridiales; Family_XIII_Incertae_Sedis; Anaerovorax & 0.1 & - & - & - & 1.4 & 0.4 & 0.5 \\
\hline Clostridiales; Clostridiaceae; Anaerobacter & - & 0.1 & 0.2 & - & 0.2 & 16.8 & 8.9 \\
\hline Clostridiales; Clostridiaceae; Clostridium & - & - & - & - & - & 0.2 & 0.2 \\
\hline Clostridiales; Clostridiaceae; Sarcina & - & - & - & - & 0.2 & 0.6 & 0.5 \\
\hline Clostridiales; Eubacteriaceae; Acetobacterium & - & - & - & - & - & 0.2 & 0.1 \\
\hline Clostridiales; Lachnospiraceae; Incertae_Sedis & - & - & - & - & - & 0.1 & 0.2 \\
\hline Clostridiales; Lachnospiraceae & - & - & - & - & 0.5 & 0.1 & 0.1 \\
\hline Clostridiales; Peptococcaceae & 1.2 & - & 2.7 & 2.6 & - & 0.8 & 0.7 \\
\hline Clostridiales; Ruminococcaceae & - & - & - & 0.1 & 0.1 & 0.1 & 0.2 \\
\hline Clostridiales; Ruminococcaceae; Fastidiosipila & - & - & 0.1 & 0.1 & 0.2 & 0.8 & 0.6 \\
\hline Clostridiales; Ruminococcaceae & - & - & - & - & 0.3 & 0.1 & - \\
\hline
\end{tabular}

reducing $\mathrm{Fe}^{\mathrm{III}}$ mineral (akaganeite) to soluble $\mathrm{Fe}^{\mathrm{II}}$, which donated electrons to methanogens to produce $\mathrm{CH}_{4}$ by utilizing $\mathrm{HCO}_{3}^{-}$ and $\mathrm{H}^{+}$. Whether Desulfobulbaceae in MFT directly reduce $\mathrm{Fe}^{\mathrm{III}}$ or shuttle electrons to $\mathrm{Fe}^{\mathrm{III}}$ through $\mathrm{S}^{2-} / \mathrm{S}^{0}$ cycling (Straub and Schink, 2004) could not be discerned here. However, the role of biogenic $\mathrm{S}^{2-}$ in chemical reduction of $\mathrm{Fe}^{\mathrm{III}}$ minerals (Raiswell and Canfield, 1998; Poulton et al., 2004) is not considered significant in our study because of the low initial concentration of $\mathrm{SO}_{4}^{2-}$ in MFT (Penner and Foght, 2010) and the formation of only small amounts of amorphous FeS during incubation.

Methanogens that reduce $\mathrm{CO}_{2}$ using $\mathrm{H}_{2}$ can also transfer electrons to $\mathrm{Fe}^{\mathrm{III}}$ either directly or through electron shuttles like extracellular quinones (Bond and Lovley, 2002; Liu et al., 2011). Solid-phase humic substances could also shuttle electrons from bacteria to $\mathrm{Fe}^{\mathrm{III}}$ oxide minerals (Roden et al., 2010). Thus, humic acids and other soluble organic fractions in MFT (Majid and Ripmeester, 1990) may serve as electron shuttles for $\mathrm{Fe}^{\mathrm{III}}$ reduction in MFT. This inadvertent extracellular $\mathrm{Fe}^{\mathrm{III}}$ reduction squanders potential energy, possibly explaining the diminished abundance of hydrogenotrophic methanogens in amended MFT (Figure 6B). Considering the proportions of microbial groups detected in MFT, we postulate that Clostridia, Synergistia, Desulfobulbaceae, and methanogens are the key players in $\mathrm{Fe}^{\mathrm{III}}$ reduction in amended MFT (Figure 7, pathways $1-4$ and 8 ).

Clay aggregate formation (Pathway IIB, Figure 1) is a primary process for dewatering and consolidation of tailings (Brown et al.,
2013). The aggregation of clay particles and formation of networks of pores explains the recovery of more water from amended MFT. Clay particle aggregation is facilitated by the formation of amorphous Fe minerals that trap and coat the charged clay surfaces. The combined results of this study (Figure 1; Pathways I and II depicting changes in pore water and solid phase chemistry, respectively) reveal that microbially-mediated geochemical processes affect aggregate structure and hence the rate of consolidation. Decreasing $\mathrm{pH}$ favors formation of face-edge structures in kaolinite (the dominant clay in MFT) by protonating aluminum and silanol groups (Si-O) exposed at the edges of kaolinite plates, thus attracting the negatively charged faces of the plates to form "house-of-cards" structures. At higher $\mathrm{pH}$, both the edges and faces of clay particles are negatively charged and dispersed. Compression of DDL by increasing $I$ (at both high and low $\mathrm{pH})$ causes particles to adhere along basal surfaces (face-face) to form "deck-of-cards" structures that generate thicker aggregates having higher density (Nasser and James, 2006; Zbik et al., 2008; Mietta et al., 2009) and decreased mobility of interstitial water. Because previous studies (Nasser and James, 2006; Zbik et al., 2008; Mietta et al., 2009) were performed using pure phyllosilicates rather than the complex mixture of phyllosilicates, iron oxyhydroxides, and organics comprising MFT, we cannot unequivocally extrapolate to the flocculation structures prevalent in amended MFT (Figures 5A-D). However, compared to the dispersed clay particles in unamended MFT (Figures 5A,C), well-structured flocculation was observed in amended MFT 


\section{Synergistaceae}

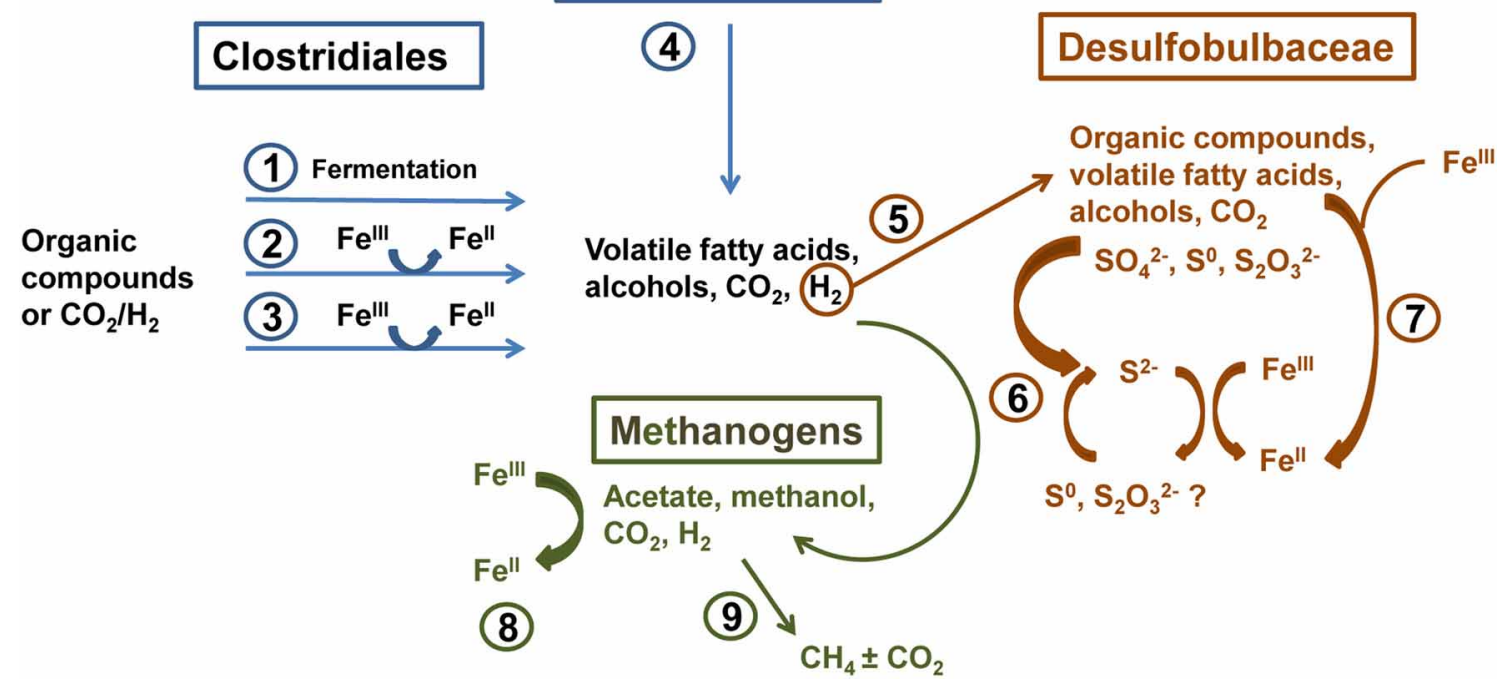

FIGURE 7 | Proposed biogeochemical reduction of Fe $\mathrm{e}^{\mathrm{III}}$ and cycling of $\mathrm{S}$ in amended MFT, based on enrichment of Clostridiales, Synergistaceae, and Desulfobulbaceae in amended MFT as revealed by 16S rRNA gene pyrosequencing (Figure 6). (1) Clostridiales ferment organic substrates yielding fatty acids, alcohols, $\mathrm{CO}_{2}$, and $\mathrm{H}_{2}$. (2) Fermentative metabolism can divert a proportion of electron flow to $\mathrm{Fe}^{\mathrm{lll}}$ reduction without conserving energy for growth (Coleman et al., 1993; Dobbin et al., 1999). (3) Some Clostridia reduce Fe ${ }^{\text {III }}$ through respiration (dissimilatory reduction) to support growth (Slobodkin et al., 1999; Kunapuli et al., 2007). (4) Synergistaceae ferment organic substrates (Zavarzina et al., 2000). (5) $\mathrm{H}_{2}$ produced by
Clostridia and Synergistaceae during fermentation can be utilized syntrophically by sulfate-reducing bacteria (SRB; e.g., Desulfobulbaceae)

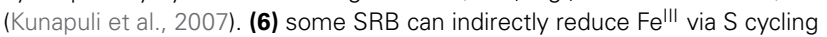
(Straub and Schink, 2004), biogenic $S^{2-}$ can chemically reduce Fe ${ }^{\text {III }}$ minerals (Raiswell and Canfield, 1998; Poulton et al., 2004), and/or (7) SRB can directly

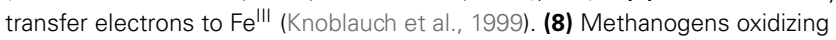
$\mathrm{H}_{2}$ can reduce $\mathrm{Fe}^{\text {III }}$ by transferring electrons to $\mathrm{Fe}^{\mathrm{III}}$ both directly and via electron shuttling (Bond and Lovley, 2002; Liu et al., 2012). (9)

Hydrogenotrophic and acetoclastic methanogens produce $\mathrm{CH}_{4}$ syntrophically with Bacteria in MFT (Siddique et al., 2011, 2012).
(Figures 5B,D), apparently dominated by card-house stacking similar to the coagulated card-house structure observed in sulfidic sediments (Macdonald et al., 2009) rather than the card-deck structure that limits dewatering of tailings (Zbik et al., 2008). Based on the current study, we proposed a model (Figure 1) describing the mechanisms encompassing various biogeochemical processes occurring simultaneously in MFT that culminate in microbially-mediated consolidation of oil sands tailings.

Our proposed mechanisms of MFT consolidation are supported in situ by measurement of more rapid MFT consolidation ( $>15$-fold faster rates) in areas of Mildred Lake Settling Basin (the largest and one of the oldest oil sands tailings ponds, and the source of MFT used in this study) having well-established methane production (Fedorak et al., 2003). This pond continuously receives tailings containing labile hydrocarbons that sustain active methanogenic communities (Penner and Foght, 2010; Siddique et al., 2011, 2012). We have also consistently observed the phenomenon of microbial consolidation of fines using oil sands tailings collected from three other oil sands operators (unpublished results), even though the tailings differ in their mineralogy, nature of extraction solvents and age of deposition.

This study uncovers complex, interwoven biogeochemical pathways that impact environmental and reclamation issues associated with oil sands tailings. Microbially-enhanced tailings consolidation can decrease on-site freshwater demand for processing oil sands ores by accelerating porewater recovery from the ponds for re-use. Biodensification may also facilitate dry landscape reclamation of MFT by complementing or possibly foregoing current management practices like chemical flocculant addition and energy-intensive centrifugation processes. However, transformation of clay minerals in situ can influence distribution of soluble metals and affect the quality of cap water associated with tailings ponds. The synthesis of new minerals such as iron sulfides may also affect the acid production potential of tailings used in surface land reclamation scenarios. Thus, the implications of this study are important for constructing and managing oil sands tailings ponds and designing future reclamation options. More broadly, microbial contributions to consolidation of diverse organic-rich clay suspensions should be investigated and incorporated into geotechnical models.

\section{ACKNOWLEDGMENTS}

We gratefully acknowledge funding from Alberta InnovatesEnergy and Environment Solutions (Tariq Siddique, Julia M. Foght), Genome Canada (Julia M. Foght), Helmholtz-Alberta Initiative (Tariq Siddique, Julia M. Foght), NSERC Discovery Grants (Tariq Siddique, Julia M. Foght), and School of Energy and Environment (Julia M. Foght, Tariq Siddique). We thank Syncrude Canada Ltd. for providing oil sands tailings and Sanimax for providing dried canola meal. At the University 
of Alberta, we thank Eleisha Underwood and Kathleen Semple for technical assistance and Phillip Fedorak, David Bressler, and Rajender Gupta for discussions. We acknowledge Canadian Light Source Inc. and technical assistance by Renfei Feng for synchrotron analyses.

\section{SUPPLEMENTARY MATERIAL}

The Supplementary Material for this article can be found online at: http://journal.frontiersin.org/journal/10.3389/fmicb. 2014.00107/abstract

\section{REFERENCES}

Ahern, C. R., McElnea, A. E., and Sullivan, L. A. (1998). Acid Sulfate Soils Laboratory Methods Guidelines. Wollongbar, NSW: Acid Sulfate Soil Management Advisory Committee.

Allen, H. E., Fu, G., and Deng, B. (1993). Analysis of acid-volatile sulfide (AVS) and simultaneously extracted metals (SEM) for the estimation of potential toxicity in aquatic sediments. Environ. Toxico. Chem. 12, 1441-1453. doi: $10.1002 /$ etc. 5620120812

An, D., Caffrey, S. M., Soh, J., Agrawal, A., Brown, D., Budwill, K., et al. (2013). Metagenomics of hydrocarbon resource environments indicates aerobic taxa and genes to be unexpectedly common. Environ. Sci. Technol. 47, 10708-10717. doi: $10.1021 /$ es 4020184

Bond, D. R., and Lovley, D. R. (2002). Reduction of Fe(III) oxide by methanogens in the presence and absence of extracellular quinones. Environ. Microbiol. 4, 115-124. doi: 10.1046/j.1462-2920.2002.00279.x

Borggaard, O. K. (1988). "Phase identification by selective dissolution techniques," in Iron in Soils and Clay Minerals, eds J. W. Stucki, B. A. Goodman, and U. Schwettmann (Dordrecht: Reidel), 83-98.

Bressler, D., Cardenas, M., Fedorak, P. M., Guigard, S., Gupta, R., Siddique, T., et al. (2010). "Microorganisms in oil sand tailings ponds influence the properties and behaviour of mature fine tailings," in Proceedings of the 2nd International Oil Sands Tailings Conference (Edmonton, AB), 44.

Brown, D., Ramos-Padrón, E., Gieg, L., and Voordouw, G. (2013). Effect of calcium ions and anaerobic microbial activity on sedimentation of oil sands tailings. Int. Biodet. Biodeg. 81, 9-16. doi: 10.1016/j.ibiod.2012.07.006

Coleman, M. L., Hedrick, D. B., Lovley, D. R., White, D. C., and Pye, K. (1993). Reduction of $\mathrm{Fe}(\mathrm{III})$ in sediments by sulphate-reducing bacteria. Nature 361, 436-438. doi: 10.1038/361436a0

Cornell, R. M., and Schwertmann, U. (2007). The Iron Oxides: Structure, Properties, Reactions, Occurrences and Uses. Darmshtadt: John Wiley \& Sons.

Dobbin, P. S., Carter, J. P., Juan, C. G.-.S., Von Höbe, M., Powell, A. K., and Richardson, D. J. (1999). Dissimilatory Fe(III) reduction by Clostridium beijerinckii isolated from freshwater sediment using $\mathrm{Fe}(\mathrm{III})$ maltol enrichment. FEMS Microbiol. Lett. 176, 131-138. doi: 10.1111/j.1574-6968.1999.tb13653.x

Fedorak, P. M., Coy, D. L., Dudas, M. J., Simpson, M. J., Renneberg, A. J., and MacKinnon, M. D. (2003). Microbially-mediated fugitive gas production from oil sands tailings and increased tailings densification rates. J. Environ. Eng. Sci. 2, 199-211. doi: 10.1139/s03-022

Fine, P., and Singer, M. J. (1989). Contribution of ferrimagnetic minerals to oxalate- and dithionite- extractable iron. Soil Sci. Soc. Am. J. 53, 191-196. doi: 10.2136/sssaj1989.03615995005300010035x

Foght, J., Aislabie, J., Turner, S., Brown, C. E., Ryburn, J., Saul, D. J., et al. (2004). Culturable bacteria in subglacial sediments and ice from two southern hemisphere glaciers. Microb. Ecol. 47, 329-340. doi: 10.1007/s00248-003-1036-5

Franke, C., Frederichs, T., and Dekkers, M. J. (2007). Efficiency of heavy liquid separation to concentrate magnetic particles. Geophys. J. Int. 170, 1053-1066. doi: 10.1111/j.1365-246X.2007.03489.x

García-Balboa, C., Vicente, M. S., Blázquez, M. L., González, F., Muñoz, J. A., and Ballester, A. (2011). Iron speciation in dissimilatory Fe(III)-reducing cultures. Geomicrobiol. J. 28, 371-379. doi: 10.1080/01490451.2010.506100

Hering, J. G., and Stumm, W. (1990). Oxidative and reductive dissolution of minerals. Rev. Mineral. Geochem. 23, 427-465.

Heron, G., Crouzet, C., Bourg, A. C. M., and Christensen, T. H. (1994). Speciation of $\mathrm{Fe}(\mathrm{II})$ and $\mathrm{Fe}(\mathrm{III})$ in contaminated aquifer sediments using chemical extraction techniques. Environ. Sci. Technol. 28, 1698-1705. doi: 10.1021/es00058a023
Jiang, S., Park, S., Yoon, Y., Lee, J.-., Wu, W.-., Phuoc Dan, N., et al. (2013). Methanogenesis facilitated by geobiochemical iron cycle in a novel syntrophic methanogenic microbial community. Environ. Sci. Tech. 47, 10078-10084. doi: $10.1021 /$ es402412c

Kimbrough, D. E., and Wakakuwa, J. R. (1989). Acid digestion for sediments, sludges, soils, and solid wastes. A proposed alternative to EPA SW 846 method 3050. Environ. Sci. Technol. 23, 898-900. doi: 10.1021/es00065a021

Knoblauch, C., Sahm, K., and Jørgensen, B. B. (1999). Psychrophilic sulfatereducing bacteria isolated from permanently cold Arctic marine sediments: Description of Desulfofrigus oceanense gen. nov., sp. nov., Desulfofrigus fragile sp. nov., Desulfofaba gelida gen. nov., sp. nov., Desulfotalea psychrophila gen. nov., sp. nov. and Desulfotalea arctica sp. nov. Int. J. Syst. Bacteriol. 49, 1631-1643. doi: 10.1099/00207713-49-4-1631

Komadel, P., and Madejová, J. (2006). "Acid activation of clay minerals," in Handbook of clay science, eds F. Bergaya, B. K. G. Theng, and G. Lagaly (Amsterdam: Elsevier), 263-287.

Kostka, J. E., and Luther III, G. W. (1994). Partitioning and speciation of solid phase iron in saltmarsh sediments. Geochim. Cosmochim. Acta 58, 1701-1710. doi: 10.1016/0016-7037(94)90531-2

Kunapuli, U., Lueders, T., and Meckenstock, R. U. (2007). The use of stable isotope probing to identify key iron-reducing microorganisms involved in anaerobic benzene degradation. ISME J. 1, 643-653. doi: 10.1038/ismej.2007.73

Kuo, S. (1996). "Phosphorus" in Methods of Soil Analysis: Part 3. Chemical Methods, ed D. L. Sparks (Madison, WI: SSSA), 869-919.

Liu, D., Dong, H., Bishop, M. E., Zhang, J., Wang, H., Xie, S., et al. (2012). Microbial reduction of structural iron in interstratified illite-smectite minerals by a sulfate-reducing bacterium. Geobiology 10, 150-162. doi: 10.1111/j.14724669.2011.00307.x

Liu, D., Wang, H., Dong, H., Qiu, X., Dong, X., and Cravotta, C. A. (2011). Mineral transformations associated with goethite reduction by Methanosarcina barkeri. Chem. Geol. 288, 53-60. doi: 10.1016/j.chemgeo. 2011.06.013

Lord, C. J. 3rd. (1982). A selective and precise method for pyrite determination in sedimentary materials. J. Sediment. Petrol. 52, 644-666. doi: 10.1306/212F7FF42B24-11D7-8648000102C1865D

Lovley, D. R., and Phillips, E. J. P. (1986). Organic matter mineralization with reduction of ferric iron in anaerobic sediments. Appl. Environ. Microbiol. 51, 683-689.

Macdonald, B. C. T., Reynolds, J. K., Kinsela, A. S., Reilly, R. J., van Oploo, P., Waite, T. D., et al. (2009). Critical coagulation in sulfidic sediments from an east-coast Australian acid sulfate landscape. Appl. Clay. Sci. 46, 166-175. doi: 10.1016/. clay.2009.07.020

Majid, A., and Ripmeester, J. A. (1990). Isolation and characterization of humic acids from Alberta oil sands and related materials. Fuel 69, 1527-1536. doi: 10.1016/0016-2361(90)90202-2

McKeague, J. A., and Day, J. H. (1966). Dithionite- and oxalate-extractable Fe and $\mathrm{Al}$ as aids in differentiating various classes of soils. Can. J. Soil Sci. 46, 13-22. doi: $10.4141 /$ cjss66-003

Mehra, O. P., and Jackson, M. L. (1960). Iron oxide removal from soils and clays by a dithionite-citrate system buffered with sodium bicarbonate. Clays Clay Miner. $5,317-323$.

Mietta, F., Chassagne, C., and Winterwerp, J. C. (2009). Shear-induced flocculation of a suspension of kaolinite as function of $\mathrm{pH}$ and salt concentration. J. Colloid Interface Sci. 336, 134-141. doi: 10.1016/j.jcis.2009.03.044

Morse, J. W., and Cornwell, J. C. (1987). Analysis and distribution of iron sulfide minerals in recent anoxic marine sediments. Mar. Chem. 22, 55-69. doi 10.1016/0304-4203(87)90048-X

Munch, J. C., and Ottow, J. C. G. (1980). Preferential reduction of amorphous to crystalline iron oxides by bacterial activity. Soil Sci. Soc. Am. J. 129, 15-21. doi: 10.1097/00010694-198001000-00004

Nasser, M. S., and James, A. E. (2006). The effect of polyacrylamide charge density and molecular weight on the flocculation and sedimentation behaviour of kaolinite suspensions. Sep. Purif. Technol. 52, 241-252. doi 10.1016/j.seppur.2006.04.005

Olsen, S. R., and Sommers, L. E. (1982). "Phosphorus," in Methods of Soil Analysis: Part II, Agronomy Series, eds A. L. Page, R. H. Miller, and D. R. Keeney (Madison, WI: American Society of Agronomy), 403-430.

Pansu, M., and Gautheyrou, J. (2006). Handbook of Soil Analysis. Mineralogical, Organic and Inorganic Methods. Berlin-Heidelberg: Springer-Verlag. 
Penner, T. J., and Foght, J. M. (2010). Mature fine tailings from oil sands processing harbour diverse methanogenic communities. Can. J. Microbiol. 56, 459-470. doi: 10.1139/W10-029

Phillips, E. J. P., and Lovley, D. R. (1987). Determination of Fe(III) and Fe(II) in oxalate extracts of sediment. Soil Sci. Soc. Am. J. 51, 938-941. doi: 10.2136/sssaj1987.03615995005100040021x

Phillips, E. J. P., Lovley, D. R., and Roden, E. E. (1993). Composition of nonmicrobially reducible Fe(III) in aquatic sediments. Appl. Environ. Microbiol. 59, 2727-2729.

Pohl, H. A. (1962). Solubility of iron sulfides. J. Chem. Eng. Data 7, 295-306. doi: 10.1021/je60013a042

Poulton, S. W., and Canfield, D. E. (2005). Development of a sequential extraction procedure for iron: implications for iron partitioning in continentally derived particulates. Chem. Geol. 214, 209-221. doi: 10.1016/j.chemgeo.2004.09.003

Poulton, S. W., Krom, M. D., and Raiswell, R. (2004). A revised scheme for the reactivity of iron (oxyhydr)oxide minerals towards dissolved sulfide. Geochim. Cosmochim. Acta 68, 3703-3715. doi: 10.1016/j.gca.2004.03.012

Prietzel, J., Thieme, J., Eusterhues, K., and Eichert, D. (2007). Iron speciation in soils and soil aggregates by synchrotron-based X-ray microspectroscopy (XANES, $\mu$-XANES). Eur. J. Soil Sci. 58, 1027-1041. doi: 10.1111/j.13652389.2006.00882.x

Raiswell, R., and Canfield, D. E. (1998). Sources of iron for pyrite formation in marine sediments. Am. J. Sci. 298, 219-245. doi: 10.2475/ajs.298.3.219

Rickard, D. (2006). The solubility of FeS. Geochim. Cosmochim. Acta 70, 5779-5789. doi: 10.1016/j.gca.2006.02.029

Rickard, D., and Luther, G. W. 3rd. (2007). Chemistry of iron sulfides. Chem. Rev. 107, 514-562. doi: 10.1021/cr0503658

Roden, E. E. (2012). Microbial iron-redox cycling in subsurface environments. Biochem. Soc. Trans. 40, 1249-1256. doi: 10.1042/BST20120202

Roden, E. E., Kappler, A., Bauer, I., Jiang, J., Paul, A., Stoesser, R., et al. (2010). Extracellular electron transfer through microbial reduction of solid-phase humic substances. Nat. Geosci. 3, 417-421. doi: 10.1038/ngeo870

Schwertmann, U., and Taylor, R. M. (1989). "Iron oxides," in Minerals in Soils Environments, eds J. B. Dixon and S. R. Weed (Madison, WI: Soil Science Society of America), 379-439.

Siddique, T., Fedorak, P. M., and Foght, J. M. (2006). Biodegradation of shortchain n-alkanes in oil sands tailings under methanogenic conditions. Environ. Sci. Technol. 40, 5459-5464. doi: 10.1021/es060993m

Siddique, T., Fedorak, P. M., Mackinnon, M. D., and Foght, J. M. (2007). Metabolism of BTEX and naphtha compounds to methane in oil sands tailings. Environ. Sci. Technol. 41, 2350-2356. doi: 10.1021/es062852q

Siddique, T., Kuznetsov, P., Kuznetsova, A., Arkell, N., Young, R., Li, C., et al. (2014). Microbially-accelerated consolidation of oil sands tailings. Pathway I: changes in porewater chemistry. Front. Microbiol. 5:106. doi: 10.3389/fmicb.2014.00106

Siddique, T., Penner, T., Klassen, J., Nesbø, C., and Foght, J. M. (2012). Microbial communities involved in methane production from hydrocarbons in oil sands tailings. Environ. Sci. Technol. 46, 9802-9810. doi: 10.1021/es302202c

Siddique, T., Penner, T., Semple, K., and Foght, J. M. (2011). Anaerobic biodegradation of longer-chain n-alkanes coupled to methane production in oil sands tailings. Environ. Sci. Technol. 45, 5892-5899. doi: 10.1021/es200649t

Slobodkin, A. I., Tourova, T. P., Kuznetsov, B. B., Kostrikina, N. A., Chernyh, N. A., and Bonch-Osmolovskaya, E. A. (1999). Thermoanaerobacter siderophilus sp. nov., a novel dissimilatory Fe(III)- reducing, anaerobic, thermophilic bacterium. Int. J. Syst. Bacteriol. 49, 1471-1478. doi: 10.1099/00207713-49-4-1471

Soh, J., Dong, X., Caffrey, S. M., Voordouw, G., and Sensen, C. W. (2013). Phoenix 2: a locally installable large-scale $16 \mathrm{~S} r R N A$ gene sequence analysis pipeline with Web interface. J. Biotechnol. 167, 393-403. doi: 10.1016/j.jbiotec.2013.07.004
Sorensen, J. (1982). Reduction of ferric iron in anaerobic, marine sediment and interaction with reduction of nitrate and sulfate. Appl. Environ. Microbiol. 43, 319-324

Stookey, L. L. (1970). Ferrozine - A new spectrophotometric reagent for iron. Anal. Chem. 42, 779-781. doi: 10.1021/ac60289a016

Straub, K. L., and Schink, B. (2004). Ferrihydrite-dependent growth of Sulfurospirillum deleyianum through electron transfer via sulfur cycling. Appl. Environ. Microbiol. 70, 5744-5749. doi: 10.1128/AEM.70.10.5744-57 49.2004

Suter, D., Siffert, C., Sulzberger, B., and Stumm, W. (1988). Catalytic dissolution of iron(III)(hydr)oxides by oxalic acid in the presence of $\mathrm{Fe}(\mathrm{II})$. Naturwissenschaften 75, 571-573. doi: 10.1007/BF00377723

US EPA. (2007). Method 3050B. Acid Digestion of Sediments, Sludges, and Soils. Available online at: http://www.epa.gov/wastes/hazard/testmethods/ sw846/online/3_series.htm

Usman, M., Hanna, K., Abdelmoula, M., Zegeye, A., Faure, P., and Ruby, C. (2012). Formation of green rust via mineralogical transformation of ferric oxides (ferrihydrite, goethite and hematite). Appl. Clay Sci. 64, 38-43. doi: 10.1016/j.clay.2011.10.008

van der Zee, C., van Raaphorst, W., and Helder, W. (2002). Fe redox cycling in Iberian continental margin sediments (NE Atlantic). J. Mar. Res. 60, 855-886. doi: $10.1357 / 002224002321505165$

Vodyanitskii, Y. N., Vasil'ev, A. A., and Gilev, V. Y. (2007). Iron minerals in soils on red-earth deposits in the Cis-Ural region. Eurasian Soil Sci. 40, 432-444. doi: $10.1134 /$ S1064229307040102

Walker, A. L. (1983). Effects of magnetite on oxalate- and dithioniteextractable iron. Soil Sci. Soc. Am. J. 47, 1022-1026. doi: 10.2136/sssaj1983.03615995004700050036x

Wallmann, K., Hennies, K., Konig, I., Petersen, W., and Knauth, H. D. (1993). New procedure for determining reactive $\mathrm{Fe}(\mathrm{III})$ and $\mathrm{Fe}(\mathrm{II})$ minerals in sediments. Limnol. Oceanogr. 38, 1803-1812. doi: 10.4319/lo.1993.38.8.1803

Zavarzina, D. G., Zhilina, T. N., Tourova, T. P., Kuznetsov, B. B., Kostrikina, N. A., and Bonch-Osmolovskaya, E. A. (2000). Thermanaerovibrio velox sp. nov., a new anaerobic, thermophilic, organotrophic bacterium that reduces elemental sulfur, and emended description of the genus Thermanaerovibrio. Int. J. Syst. Evol. Microbiol. 50, 1287-1295. doi: 10.1099/00207713-50-3-1287

Zbik, M. S., Smart, R. S. C., and Morris, G. E. (2008). Kaolinite flocculation structure. J. Colloid Interface Sci. 328, 73-80. doi: 10.1016/j.jcis.2008. 08.063

Conflict of Interest Statement: The authors declare that the research was conducted in the absence of any commercial or financial relationships that could be construed as a potential conflict of interest.

Received: 03 December 2013; accepted: 02 March 2014; published online: 21 March 2014.

Citation: Siddique T, Kuznetsov P, Kuznetsova A, Li C, Young R, Arocena JM and Foght JM (2014) Microbially-accelerated consolidation of oil sands tailings. Pathway II: solid phase biogeochemistry. Front. Microbiol. 5:107. doi: 10.3389/fmicb.2014.00107

This article was submitted to Microbiological Chemistry, a section of the journal Frontiers in Microbiology.

Copyright (c) 2014 Siddique, Kuznetsov, Kuznetsova, Li, Young, Arocena and Foght. This is an open-access article distributed under the terms of the Creative Commons Attribution License (CC BY). The use, distribution or reproduction in other forums is permitted, provided the original author(s) or licensor are credited and that the original publication in this journal is cited, in accordance with accepted academic practice. No use, distribution or reproduction is permitted which does not comply with these terms. 